Article

\title{
Design and Synthesis of Novel Xyloketal Derivatives and Their Protective Activities against $\mathrm{H}_{2} \mathrm{O}_{2}$-Induced HUVEC Injury
}

\author{
Shixin Liu ${ }^{1, \dagger}$, Rong Luo ${ }^{1, \dagger}$, Qi Xiang ${ }^{2,3}$, Xianfang Xu ${ }^{1}$, Liqin Qiu ${ }^{1}$ and Jiyan Pang ${ }^{1, *}$ \\ 1 School of Chemistry \& Chemical Engineering, Sun Yat-Sen University, Guangzhou 510275, China; \\ E-Mails: 1sxinhoho@gmail.com (S.L.); gdzdlr@163.com (R.L.); xuxianf@mail.sysu.edu.cn (X.X.); \\ qiuliqin@mail.sysu.edu.cn (L.Q.) \\ 2 Institute of Biomedicine \& Guangdong Provincial Key Laboratory of Bioengineering Medicine, \\ Jinan University, Guangzhou 510632, China; E-Mail: txiangqi@jnu.edu.cn \\ 3 Department of Pharmacy, Jinan University, Guangzhou 510632, China
}

$\dagger$ These authors contributed equally to this work.

* Author to whom correspondence should be addressed; E-Mail: cespjy@mail.sysu.edu.cn; Tel./Fax: +86-20-84036554.

Academic Editor: Orazio Taglialatela-Scafati

Received: 27 November 2014 / Accepted: 4 February 2015 / Published: 12 February 2015

\begin{abstract}
In this work, we designed and synthesized a series of amide derivatives (1-13), benzoxazine derivatives (16-28) and amino derivatives (29-30) from xyloketal B. All 28 new derivatives and seven known compounds $(\mathbf{1 4}, \mathbf{1 5}, \mathbf{3 1}-\mathbf{3 5})$ were evaluated for their protection against $\mathrm{H}_{2} \mathrm{O}_{2}$-induced HUVEC injury. 23 and 24 exhibited more potential protective activities than other derivatives; and the $\mathrm{EC}_{50}$ values of them and the leading compound 31 (xyloketal B) were 5.10, 3.59 and $15.97 \mu \mathrm{M}$, respectively. Meanwhile, a comparative molecular similarity indices analysis (CoMSIA) was constructed to explain the structural activity relationship of these xyloketal derivatives. This 3D QSAR model from CoMSIA suggested that the derived model exhibited good predictive ability in the external test-set validation. Derivative $\mathbf{2 4}$ fit well with the COMSIA map, therefore it possessed the highest activity of all compounds. Compounds 23, 24 and 31 (xyloketal B) were further to examine in the JC-1 mitochondrial membrane potential (MMP) assay of HUVECs using flow cytometry (FCM). The result indicated that $\mathbf{2 3}$ and $\mathbf{2 4}$ significantly inhibited $\mathrm{H}_{2} \mathrm{O}_{2}$-induced decrease of the cell mitochondrial membrane potential $(\Delta \Psi \mathrm{m})$ at $25 \mu \mathrm{M}$. Collectively, the protective effects of xyloketals on $\mathrm{H}_{2} \mathrm{O}_{2}$-induced endothelial cells may be generated from oxidation action by restraining ROS and reducing the MMP.
\end{abstract}


Keywords: xyloketals; $\mathrm{H}_{2} \mathrm{O}_{2}$; oxidative stress; 3D-QSAR; HUVECs

\section{Introduction}

Cardiovascular disease (CVD) has drawn significant attention in recent years because it has become the leading cause of mortality worldwide, affecting people from every income level. Reactive oxygen species (ROS), including $\mathrm{H}_{2} \mathrm{O}_{2}, \mathrm{OH}^{-}$, $\mathrm{NO}$, and $\mathrm{ONOO}^{-}$, play key roles in the pathogenesis of many CVDs, such as hypertension and atherosclerosis (As). The ROS-induced oxidative stress in cardiac and vascular is closely connected with the endothelial dysfunction in disease initiation and progression. Reactive oxygen species (ROS) are generated under pathological conditions, such as ischemia-reperfusion and inflammation, and activate pro-apoptotic and anti-apoptotic signaling programs in endothelial cells [1]. As one of the most common ROS, hydrogen peroxide $\left(\mathrm{H}_{2} \mathrm{O}_{2}\right)$ can easily cross the plasma membrane, produce a highly reactive radical $\mathrm{OH}$, and lead to cell and tissue damage [2,3]. The generation of $\mathrm{H}_{2} \mathrm{O}_{2}$ plays a key role in the atherosclerotic progression. $\mathrm{H}_{2} \mathrm{O}_{2}$ mediates various cellular responses. Direct or indirect stimulation by $\mathrm{H}_{2} \mathrm{O}_{2}$ due to its intracellular production could activate various cellular pathways, including calcium release, protein tyrosine kinase, mitogen-activated protein kinases (MAPKs), transcription factor $\mathrm{NF}-\kappa \mathrm{B}$, and the induction of cell apoptosis [4-7]. Thus, $\mathrm{H}_{2} \mathrm{O}_{2}$ has been extensively used as an oxidative stimulus to induce oxidative stress in in vitro models. As the major type of endothelial cells, human umbilical vein endothelial cells (HUVECs) are commonly accepted as a model cell to explore the mechanisms involved in the pathogenesis of CVDs [8].

Mitochondrion serve as a pivotal decision center in many types of apoptotic response: they release a variety of death-promoting factors from their inter-membrane spaces into the cytosol, triggering an increase in mitochondria permeability and leading to consequences of mitochondrial dysfunction (e.g., disruption of the mitochondrial membrane potential $\Delta \Psi \mathrm{m}$ ) $[9,10]$. Mitochondria are considered the main source of ROS in the cell. Unless adequately detoxified, superoxide causes mitochondrial oxidative stress and may contribute to a decline in mitochondrial function.

Xyloketals are a type of novel compounds that possess unique molecular structures. They are isolated from the marine mangrove fungus Xylaria sp. (\#2508) (Chart 1) [11,12]. We previously demonstrated that xyloketal B has protective action against a variety of pathophysiological stimuli, such as oxLDL, oxygen-glucose deprivation (OGD) and 1-methyl-4-phenylpyridinium (MPP+), in different disease models [13-18]. Thus, xyloketal B might be a good candidate for further development as an antioxidant medicine in cardiovascular diseases. However, its clinical development may be difficult due to water insolubility. Structure-activity relationship analyses in previous reports have demonstrated that the characteristic substituted groups at the $\mathrm{C}-12$ or $\mathrm{C}-13$ position of xyloketal $\mathrm{B}$ are key functional groups for its antioxidative effect. To improve the solubility and biological activity of xyloketal B, some amino groups can be introduced at the $\mathrm{C}-12$ or $\mathrm{C}-13$ position of this type of structure, and the corresponding acid salts could be prepared in the future. Because of the complexity of the stereoselective synthesis of xyloketals, it is difficult to provide a significant amount of optically pure samples for biological activity evaluation. We decided to begin the studies using racemic xyloketal B. In this paper, we designed and synthesized a new series of derivatives (Chart 2) from xyloketal B, including a series of C-13 xyloketal 
amide derivatives (1-13); xyloketal benzoxazine derivatives (16-28) using a one-pot reaction of xyloketal B, formaldehyde and different primary amines; and xyloketal amino derivatives (29-30) that C-13 substituted using different secondary amines. All 28 new derivatives and 7 known compounds (14, 15, 31-35) were evaluated for their protection against $\mathrm{H}_{2} \mathrm{O}_{2}$-induced HUVEC injury. Then, a comparative molecular similarity indices analysis (CoMSIA) was constructed using the SYBYL programming package (version 7.3.5) to explain the structural activity relationship of these xyloketal derivatives $[19,20]$. The training set and test set were randomly divided out of a total of 35 molecules. A training set of 30 molecules was used to construct the QSAR model, and a training set of five molecules was used to validate it. Mitochondria are considered the main source of reactive oxygen species (ROS) in cells [21,22]. Therefore, we investigated whether xyloketals could protect mitochondria through inhibition of ROS. Any compound with high antioxidative action was further investigated in the JC-1 mitochondrial membrane potential (MMP) assay of HUVECs using flow cytometry (FCM).

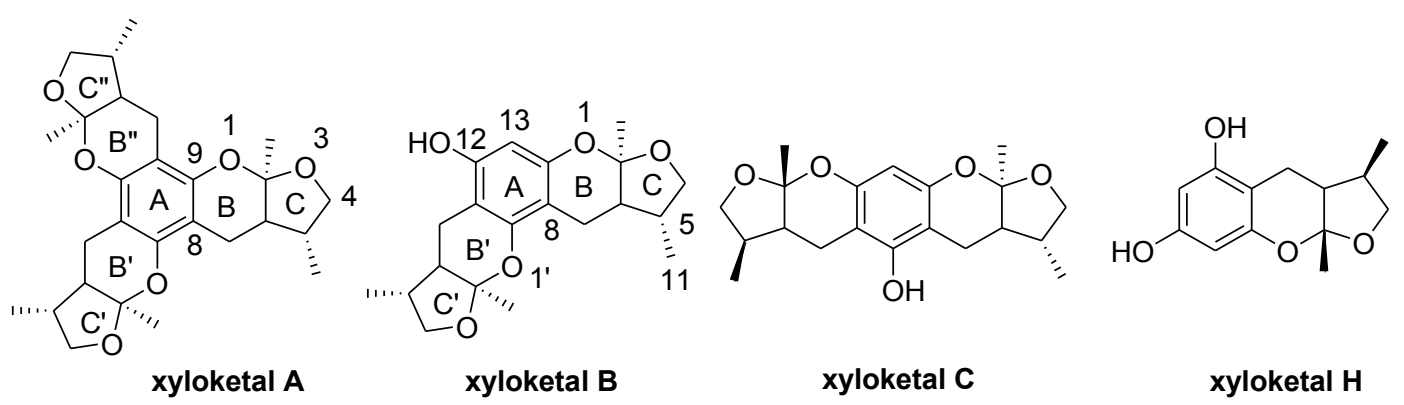

Chart 1. Structures of xyloketal A, B, C, H.
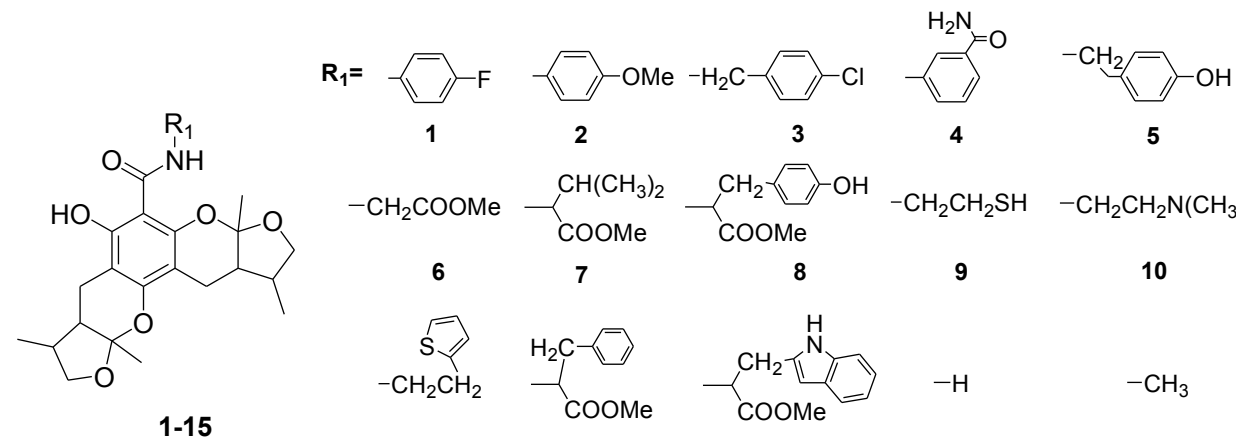

$-\mathrm{CH}_{2} \mathrm{CH}_{2} \mathrm{SH}-\mathrm{CH}_{2} \mathrm{CH}_{2} \mathrm{~N}\left(\mathrm{CH}_{3}\right)_{2}$
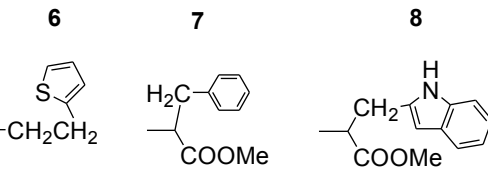

10

11

12

13

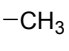

15
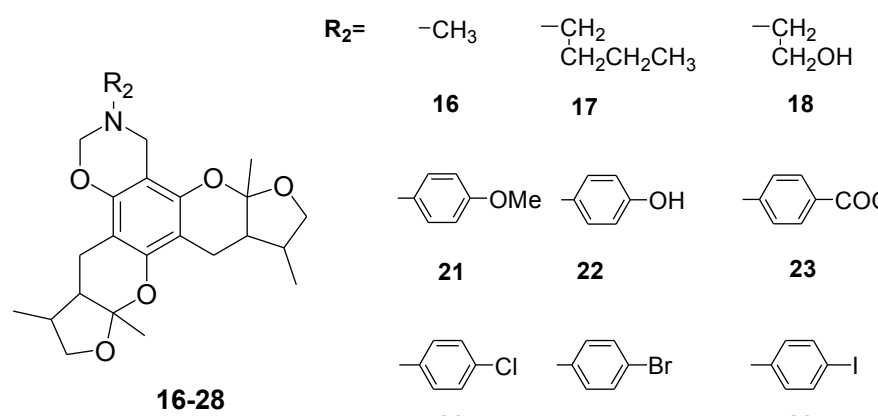

$-\mathrm{CH}_{2} \mathrm{CH}_{2}$

18

19

20

26

27
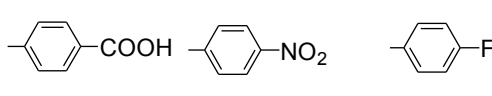

23

24

25

Chart 2. Cont. 


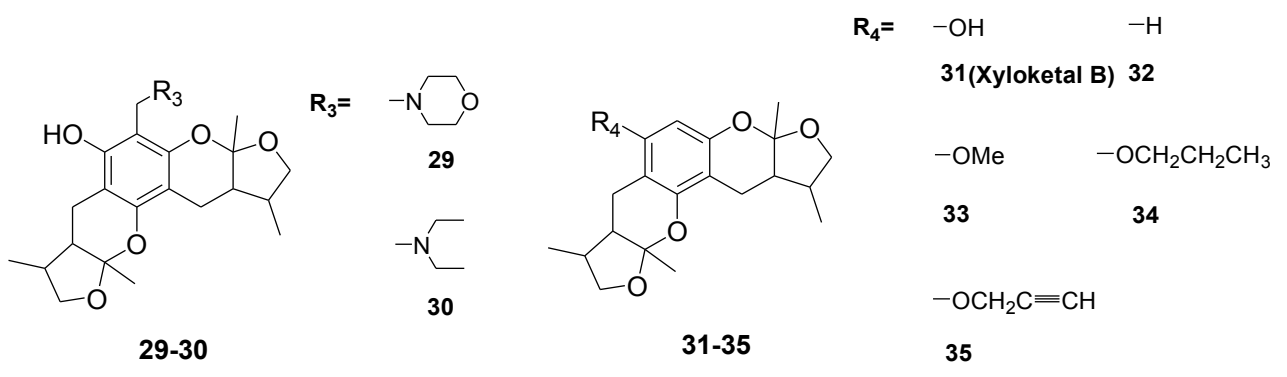

Chart 2. Structures of xyloketal derivatives 1-35.

\section{Results and Discussion}

\subsection{Chemistry}

The general synthetic routes of compounds 1-35 are outlined in Schemes 1-3. All the new compounds were prepared from xyloketal B and xyloketal B acid that were gained from synthetic way in the ordinary state without any asymmetric factors [16]. New xyloketal amides 1-13 were obtained via a condensation reaction between xyloketal $\mathrm{B}$ acid and the corresponding amines in the presence of (benzotriazol-1yloxy)tris(dimethylamino)phosphonium hexafluorophosphate (BOP) and $N, N$-diisopropylethylamine (DIEA) (Scheme 1). Interestingly, the one-pot Mannich reaction of xyloketal B, formaldehyde and different primary amines afforded a series of novel xyloketal derivatives 16-28 bearing an 1,3-oxazine moiety. Instead of primary amines, the Mannich reaction of secondary amines, xyloketal B and formaldehyde generated C-13 substituted amine derivatives 29-30 (Scheme 3). All the new compounds were fully characterized using MS and NMR. Moreover, all of the examined compounds were synthesized as racemic mixtures from synthetic xyloketal B and xyloketal B acid and no asymmetric synthesis was applied. Their stereo features are the same as xyloketal B and xyloketal B acid. The stereochemistry of these xyloketal derivatives was complicated. In principle, the two oxygen-containing pyran and furan rings $\mathrm{B}$ and $\mathrm{C}$ can be connected in a cis or trans fashion. The methyl group at C-5 or $\mathrm{C}-5^{\prime}$ could be cis or trans with respect to the stereogenic centers at the junction at C-2 or C-2' and C-6 or C- $6^{\prime}$. However, previous studies indicated that rings $\mathrm{B}$ and $\mathrm{C}$ or $\mathrm{B}^{\prime}$ and $\mathrm{C}^{\prime}$ were cis for all condensations leading to xyloketal derivatives in the natural and synthetic compounds [18,23-29], thus only two sets of stereoisomers of xyloketals can be formed: syn, anti and syn, syn types. Moreover, C-2/C-5 methyl in cis orientation occupied dominant position both in experimental and theoretical results [29]. We previously also reported that synthetic xyloketal B and xyloketal B acid were characterized as mixtures of stereoisomers, including the enantiomers and diastereoisomers [16,18,30], and the ratio of two sets of diastereoisomers syn, anti and syn, syn was about 1:1 via NMR analysis. Similar to our previous studies, at this time, racemic mixtures of all new derivatives were consisted of two sets of diastereoisomers (Chart 3, syn, anti a and syn, syn b). Every diastereoisomer had four enantiomer pairs depending on C-5/C-5' methyl in cis or trans, and the isomer with C-2/C-5 and C-2'/C-5' methyl all in cis may take greatest proportion in these four enantiomer pairs in according to previous studies. The very close relationship of the diastereoisomers syn, anti and syn, syn was evident in NMR spectra. Though with overlapping of nearly identical sets of signals, two sets of signal peaks could still be detected in ${ }^{1} \mathrm{H}$ and ${ }^{13} \mathrm{C}$ NMR spectra assigned to isomers syn, anti and syn, syn with approximate ratio of $\sim 1: 1$. Taking 24 
as an example, both the ${ }^{1} \mathrm{H}$ and ${ }^{13} \mathrm{C}$ NMR spectra of 24 showed evidence of the diastereoisomers 24a and 24b (Figure 1). Obviously, in ${ }^{1} \mathrm{H}$ NMR, methyl (10 and 10') at C-2 and C-2' showed as two peaks respectively $(\delta=1.49,1.48$, and $1.52,1.50 \mathrm{ppm})$ relative to two single peak ( $\delta=1.50$ and $1.52 \mathrm{ppm})$ of 10 and $10^{\prime}$ in the natural xyloketal B [11] (Figure 1A), in addition, the integrals of the hydrogen atoms of two peaks indicated an approximately 1: 1 ratio of diastereoisomers $\mathbf{2 4 a}$ and $\mathbf{2 4 b}$. The ${ }^{13} \mathrm{C}$ NMR spectrum was more instructive (Figure 1B). The methyl (C-10, C-10') and (C-11, C-11') both presented as four closely packed peaks ( $\delta=23.0,22.9,22.8,22.6$ and 16.0, 15.9, 15.9, $15.8 \mathrm{ppm}$ ). Moreover, the aromatic carbon atom (C-13) also appeared as two peaks $(\delta=98.9$ and $99.0 \mathrm{ppm})$. These peaks all proved that compound $\mathbf{2 4}$ consisted of two sets of diastereoisomers. However, the enantiomers could not be found by NMR analysis because of their identical NMR spectra. Separating these stereoisomers via chromatography was very difficult. Therefore, all xyloketal derivatives were used directly in the biological screening without separating the stereoisomers this time. These compounds possessed the same structural framework; the only differences were different substituents at the $\mathrm{C}-12$ or $\mathrm{C}-13$ position of the aromatic ring. Although the test compounds are enantiomeric and diastereomeric mixtures, their activities and SAR analysis could be obtained.

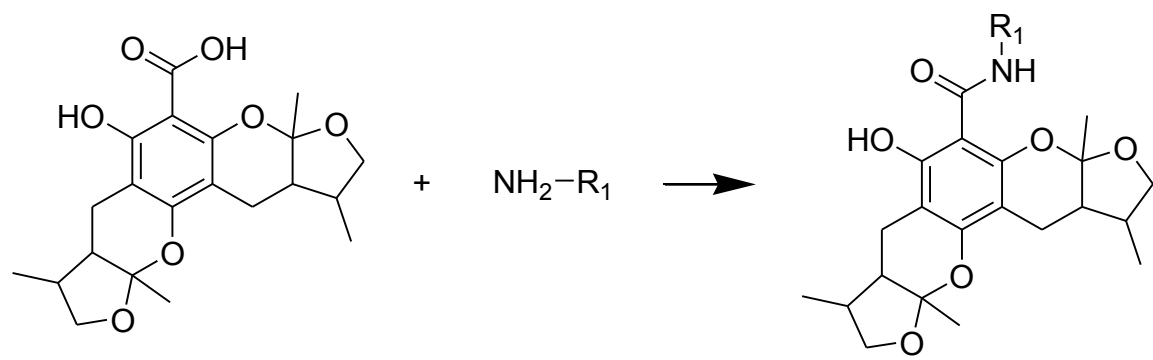

Scheme 1. Synthesis of compounds 1-13. Reagents and conditions: BOP, DIEA, DMF, room temp.

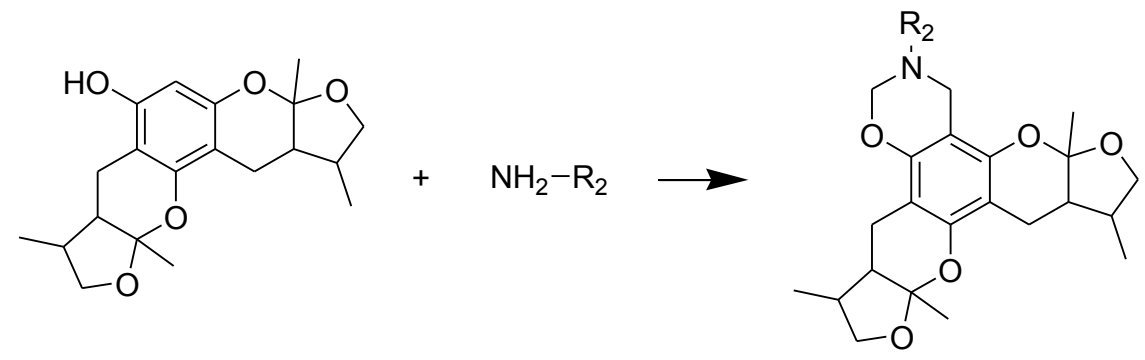

Scheme 2. Synthesis of compounds 16-28. Reagents and conditions: THF, HCHO, room temp.

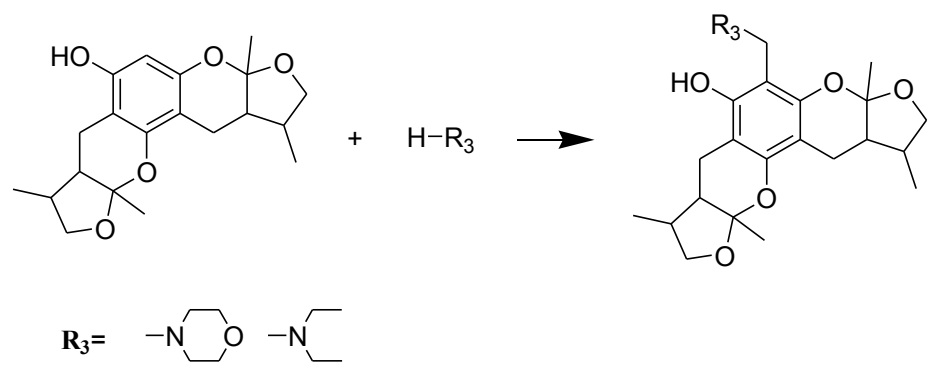

Scheme 3. Synthesis of compounds 29-30. Reagents and conditions: THF, HCHO, room temp. 


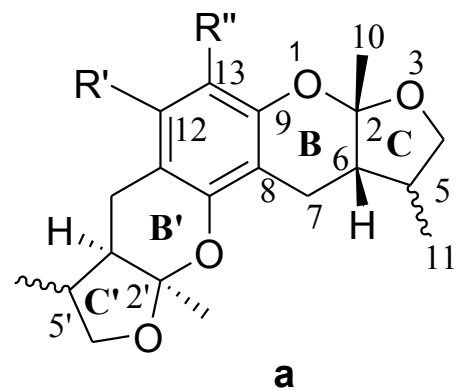<smiles>[R7]c1c([R])c2c(c3c1C[C@@H]1[C@H](C)[C@](C)(OC[C@@H]1C)O3)O[C@@]1(C)OC[C@@H](C)[C@@H]1C2</smiles>

Chart 3. All stereoisomers of synthesized xyloketal structures.

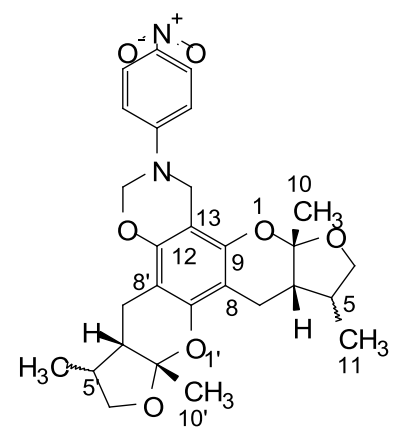

$24 a$

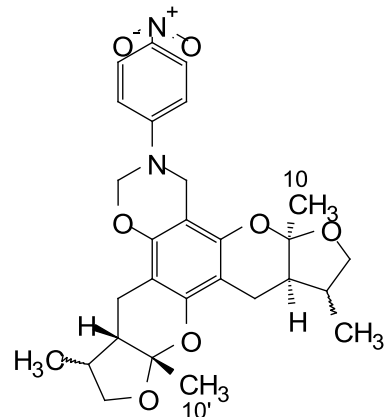

24b
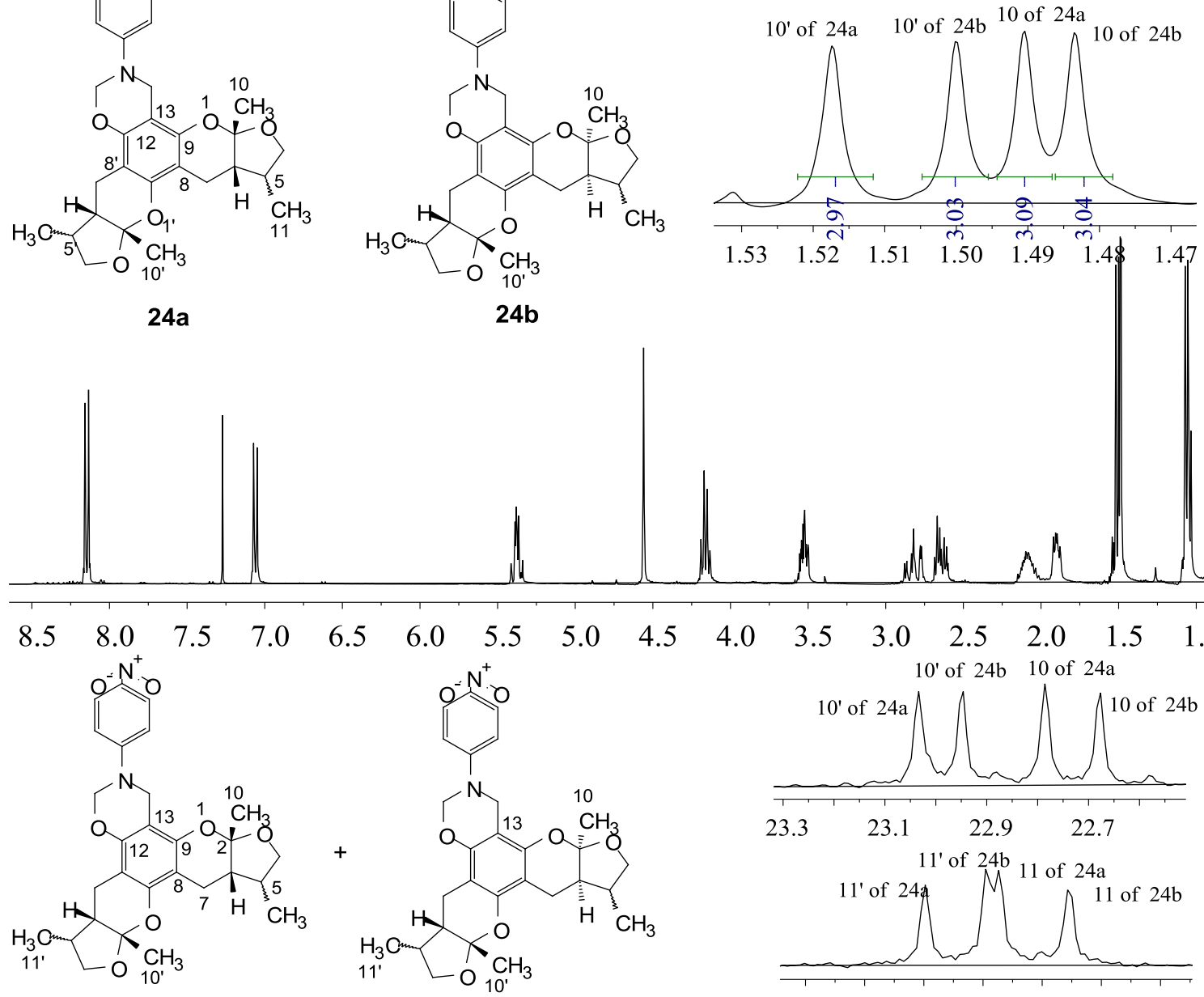

24b

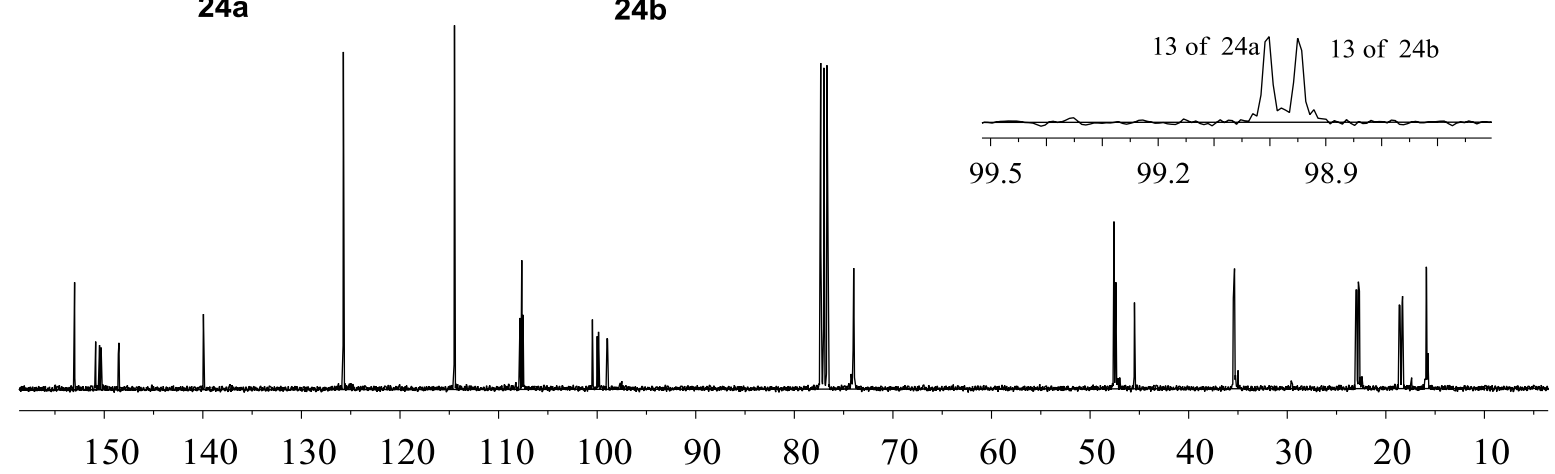

Figure 1. ${ }^{1} \mathrm{H}$ and ${ }^{13} \mathrm{C}$ NMR spectra of $\mathbf{2 4}$. 


\subsection{Xyloketal Derivatives Protected Endothelial Cells against $\mathrm{H}_{2} \mathrm{O}_{2}$-Induced Injury Assay}

The apoptosis of HUVECs caused by ROS has been implicated in numerous pathophysiological processes of CVDs. An important source of endogenous ROS is generated from $\mathrm{H}_{2} \mathrm{O}_{2}$, and it has been proven that ROS are involved in the apoptosis of ECs [31,32]. Using a similar culture system, we have shown that xyloketals had no significant effects on cell viability up to $100 \mu \mathrm{M}$ in the MTT assay. Accordingly, the protection of xyloketals 1-35 at concentrations of 1 and $10 \mu \mathrm{M}$ was applied for the following $\mathrm{H}_{2} \mathrm{O}_{2}(600 \mu \mathrm{M})$-induced injury of HUVECs, and apocynin $(1$ and $10 \mu \mathrm{M})$ was used as a positive control. The results (Table 1, Figure 2) showed that some compounds exhibited strong antioxidative activities, in both morphological changes and inhibition of cell apoptosis. Among them, benzo-1,3-oxazine xyloketal derivatives $\mathbf{2 3}$ and $\mathbf{2 4}$ displayed greater potential protective activities than other derivatives with cell viabilities $83.07 \%$ and $86.08 \%$. Furthermore, to evaluate the activities of these two most significant compounds clearly, the EC50 values in HUVECs ranged from 1-50 $\mu \mathrm{M}$ of 23, 24 and the leading compound xyloketal B (31) were determined with 5.10, 3.59 and $15.97 \mu \mathrm{M}$, respectively (Table 2). Thus, new candidates with amino groups, which could be prepared the corresponding acid salts in the future to improve their water-insolubility, will be the promising compounds for further evaluation in the treatment of cardiovascular diseases.

Table 1. Protective effects of xyloketal derivatives against $\mathrm{H}_{2} \mathrm{O}_{2}$-induced cell injury.

\begin{tabular}{|c|c|c|c|c|c|}
\hline \multirow{2}{*}{ No. } & \multicolumn{2}{|c|}{ Cell Viability/\% of Control } & \multirow{2}{*}{ No. } & \multicolumn{2}{|c|}{ Cell Viability/\% of Control } \\
\hline & $10 \mu \mathrm{M}$ & $1 \mu \mathrm{M}$ & & $10 \mu \mathrm{M}$ & $1 \mu \mathrm{M}$ \\
\hline 1 & $48.41 \pm 4.47$ & $45.38 \pm 3.89$ & 19 & $52.94 \pm 6.80$ & $57.32 \pm 4.59$ \\
\hline 2 & $54.19 \pm 4.11$ & $45.57 \pm 6.78$ & 20 & $46.63 \pm 1.55$ & $43.77 \pm 4.70$ \\
\hline 3 & $55.36 \pm 7.21$ & $49.33 \pm 5.34$ & 21 & $43.49 \pm 5.28$ & $54.78 \pm 5.16$ \\
\hline 4 & $35.49 \pm 3.90$ & $48.19 \pm 4.96$ & 22 & $53.23 \pm 6.86$ & $12.85 \pm 2.53$ \\
\hline 5 & $6.15 \pm 1.29$ & $5.96 \pm 1.36$ & 23 & $83.07 \pm 5.01$ & $59.07 \pm 6.76$ \\
\hline 6 & $45.41 \pm 5.29$ & $50.84 \pm 7.46$ & 24 & $86.08 \pm 4.87$ & $49.95 \pm 5.92$ \\
\hline 7 & $42.28 \pm 6.27$ & $46.64 \pm 4.76$ & 25 & $44.20 \pm 5.95$ & $50.67 \pm 7.66$ \\
\hline 8 & $23.32 \pm 2.22$ & $8.29 \pm 2.08$ & 26 & $30.47 \pm 2.19$ & $35.97 \pm 2.28$ \\
\hline 9 & $46.98 \pm 4.63$ & $48.61 \pm 5.84$ & 27 & $34.02 \pm 4.76$ & $39.33 \pm 4.00$ \\
\hline 10 & $46.84 \pm 7.17$ & $46.34 \pm 6.13$ & 28 & $34.79 \pm 4.82$ & $33.18 \pm 3.92$ \\
\hline 11 & $51.56 \pm 8.03$ & $49.66 \pm 5.51$ & 29 & $67.53 \pm 6.68$ & $48.30 \pm 4.91$ \\
\hline 12 & $25.51 \pm 3.94$ & $23.76 \pm 2.24$ & 30 & $62.41 \pm 7.52$ & $46.04 \pm 5.92$ \\
\hline 13 & $16.31 \pm 2.19$ & $15.91 \pm 2.30$ & 31 & $60.43 \pm 2.89$ & $44.46 \pm 2.24$ \\
\hline 14 & $59.42 \pm 4.76$ & $53.14 \pm 4.03$ & 32 & $62.85 \pm 7.96$ & $53.00 \pm 6.14$ \\
\hline 15 & $47.72 \pm 5.41$ & $54.35 \pm 6.44$ & 33 & $55.24 \pm 5.09$ & $48.48 \pm 4.13$ \\
\hline 16 & $48.40 \pm 4.02$ & $48.01 \pm 5.62$ & 34 & $68.50 \pm 2.06$ & $24.06 \pm 2.87$ \\
\hline 17 & $49.11 \pm 6.50$ & $47.62 \pm 4.30$ & 35 & $71.67 \pm 5.28$ & $63.16 \pm 6.32$ \\
\hline 18 & $29.64 \pm 3.88$ & $30.88 \pm 3.59$ & Apo-cynin & $69.03 \pm 0.68$ & $65.48 \pm 0.70$ \\
\hline
\end{tabular}

Datas are representative of means \pm S.E.M. $n=6$ wells for each group.

Table 2. The EC50 of 23, 24 and $\mathbf{3 1}$ (xyloketal B).

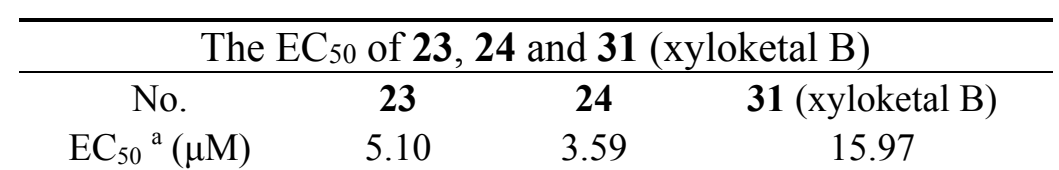

${ }^{a}$ Each experiment was independently performed six times and expressed as means. 


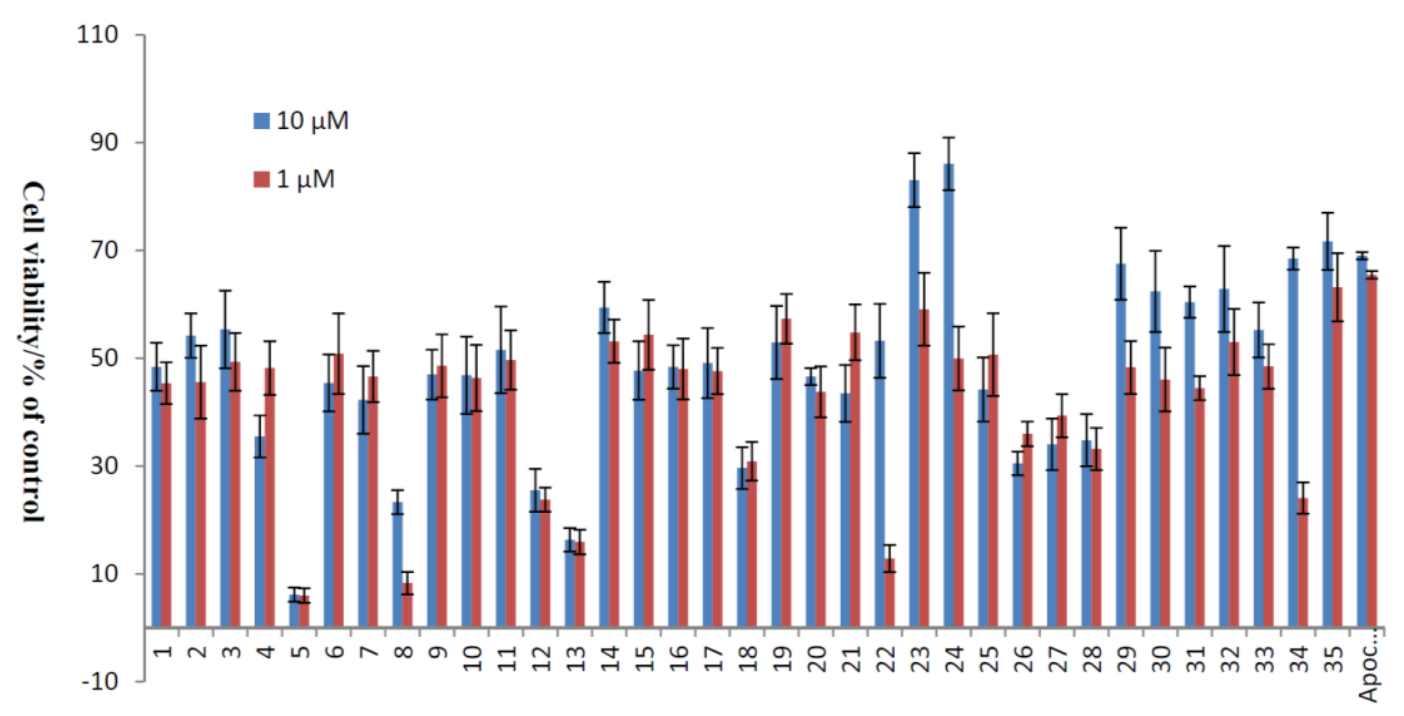

Figure 2. Protective effects of xyloketal derivatives against $\mathrm{H}_{2} \mathrm{O}_{2}$-induced cell injury. HUVECs were pre-incubated with $10 \mu \mathrm{M}$ xyloketal derivatives (blue bars) or $1 \mu \mathrm{M}$ xyloketal derivatives (red bars) for $30 \mathrm{~min}$, and $600 \mu \mathrm{M} \mathrm{H}_{2} \mathrm{O}_{2}$ was added to the medium. After incubation for $20 \mathrm{~h}$, cell viability was determined using MTT reduction assay. Apocynin was used as positive control. Values are the mean $\pm \mathrm{SD}(n=6)$.

\subsection{The Structural Activity Relationship of Xyloketals on a COMSIA Model}

To explore the SAR of these xyloketals, a COMSIA model was constructed to explain the structural activity relationship of xyloketal $B$ and its analogs. These compounds had the same structural framework, to unify the evaluation standard; therefore, a dominating stereoisomer of a previously reported xyloketal structure was selected for use in this SAR analysis (Chart 4) [16,18,30]. The statistical parameters of the 3D-QSAR models are shown in Table 3. For an acceptable standard of a 3D-QSAR model, the $q^{2}$ training (cross-validated regression coefficient) of the training set should be greater than 0.5 , and the $r^{2}$ training (conventional regression coefficient) should be greater than 0.9 . The LOO PLS analysis of the model gives a $q^{2}$ value of 0.577 at six components, together with the conventional regression coefficient $r^{2}$ of 0.988 and a standard error of estimate of 0.041 .

Table 3. Statistical parameters of the CoMSIA models.

\begin{tabular}{cc}
\hline \multicolumn{2}{c}{ Training Set } \\
\hline$q^{2}$ & 0.577 \\
$r^{2}$ & 0.988 \\
SEE $^{\mathrm{a}}$ & 0.041 \\
$F^{\mathrm{b}}$ & 316.828 \\
Optimal components & 6 \\
\hline Test set & \\
\hline$q_{\text {test }}{ }^{2}$ & 0.648 \\
$r_{\text {test }}{ }^{2}$ & 0.858 \\
$k$ & 0.987 \\
\hline${ }^{\text {a Standard error of estimate; }}{ }^{\mathrm{b}} F$-test value.
\end{tabular}

a Standard error of estimate; ${ }^{\mathrm{b}} \mathrm{F}$-test value. 


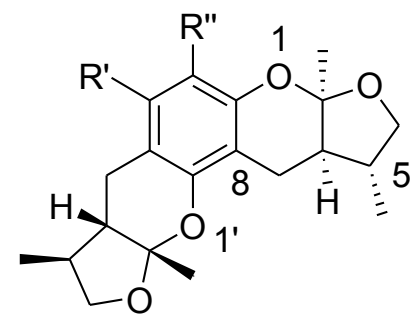

Chart 4. A stereoisomer of synthesized xyloketal structure used to 3D SAR analysis.

Furthermore, the significance and predictability of QSAR models should be further proven by an external test set using the following criteria: $q^{2}>0.5, r^{2}>0.6$ and $0.85<k<1.15$ (k refers to the slope of the regression line between the experimental and the predicted biological activities). A graphical representation of the predicted and actual values is displayed in Figure 3. An excellent correlation between the experimental and predicted biological activities is shown in Figure 3 for the test set $\left(q^{2}=0.648, r^{2}=0.858\right.$, and $\left.k=0.987\right)$. In summary, all statistical data satisfied the recommended criteria, suggesting that the derived model exhibits good predictive ability in the external test-set validation. The predicted and actual values are shown for comparison in Table 4.

Table 4. Structures, experimental and predicted values of the xyloketal derivatives.

\begin{tabular}{ccccc}
\hline No. & Cell Viability/\% of Control & Actual Value & Predicted Value & Residual Value \\
\hline 1 & $48.41 \pm 4.47$ & 4.972 & 4.984 & -0.012 \\
2 & $54.19 \pm 4.11$ & 5.026 & 5.029 & -0.003 \\
3 & $55.36 \pm 7.21$ & 4.901 & 4.900 & 0.001 \\
$4^{*}$ & $35.49 \pm 3.90$ & 4.740 & 4.772 & -0.032 \\
5 & $6.15 \pm 1.29$ & 4.264 & 4.276 & -0.012 \\
$6^{*}$ & $45.41 \pm 5.29$ & 4.935 & 5.101 & -0.166 \\
7 & $42.28 \pm 6.27$ & 4.865 & 4.811 & 0.054 \\
$8^{*}$ & $23.32 \pm 2.22$ & 4.515 & 4.476 & 0.039 \\
9 & $46.98 \pm 4.63$ & 4.947 & 4.965 & -0.018 \\
10 & $46.84 \pm 7.17$ & 5.103 & 5.109 & 0.006 \\
11 & $51.56 \pm 8.03$ & 4.857 & 4.886 & -0.029 \\
12 & $25.51 \pm 3.94$ & 4.534 & 4.553 & -0.019 \\
13 & $16.31 \pm 2.19$ & 4.290 & 4.288 & 0.002 \\
$14 *$ & $59.42 \pm 4.76$ & 5.222 & 5.038 & 0.184 \\
15 & $47.72 \pm 5.41$ & 5.060 & 5.026 & 0.034 \\
16 & $48.40 \pm 4.02$ & 4.972 & 5.034 & -0.062 \\
17 & $49.11 \pm 6.50$ & 4.985 & 4.956 & 0.029 \\
18 & $29.64 \pm 3.88$ & 4.475 & 4.454 & 0.021 \\
19 & $52.94 \pm 6.80$ & 5.051 & 5.061 & -0.010 \\
20 & $46.63 \pm 1.55$ & 4.941 & 4.957 & -0.016 \\
21 & $43.49 \pm 5.28$ & 5.025 & 4.972 & 0.053 \\
22 & $53.23 \pm 6.86$ & 4.951 & 4.976 & -0.025 \\
23 & $83.07 \pm 5.01$ & 5.658 & 5.674 & -0.016 \\
24 & $86.08 \pm 4.87$ & 5.801 & 5.811 & -0.010 \\
25 & $44.20 \pm 5.95$ & 5.016 & 4.948 & 0.068 \\
\hline
\end{tabular}


Table 4. Cont.

\begin{tabular}{ccccc}
\hline 26 & $30.47 \pm 2.19$ & 4.784 & 4.889 & -0.105 \\
27 & $34.02 \pm 4.76$ & 4.867 & 4.845 & 0.022 \\
28 & $34.79 \pm 4.82$ & 4.781 & 4.770 & 0.011 \\
29 & $67.53 \pm 6.68$ & 5.430 & 5.363 & 0.067 \\
30 & $62.41 \pm 7.52$ & 5.042 & 5.054 & -0.012 \\
31 & $60.43 \pm 2.89$ & 5.181 & 5.204 & -0.023 \\
32 & $62.85 \pm 7.96$ & 5.311 & 5.280 & 0.031 \\
33 & $55.24 \pm 5.09$ & 5.246 & 5.281 & -0.035 \\
$34 *$ & $68.50 \pm 2.06$ & 5.337 & 5.286 & 0.051 \\
35 & $71.67 \pm 5.28$ & 5.314 & 5.293 & 0.021 \\
\hline
\end{tabular}

* Molecules in the test set.

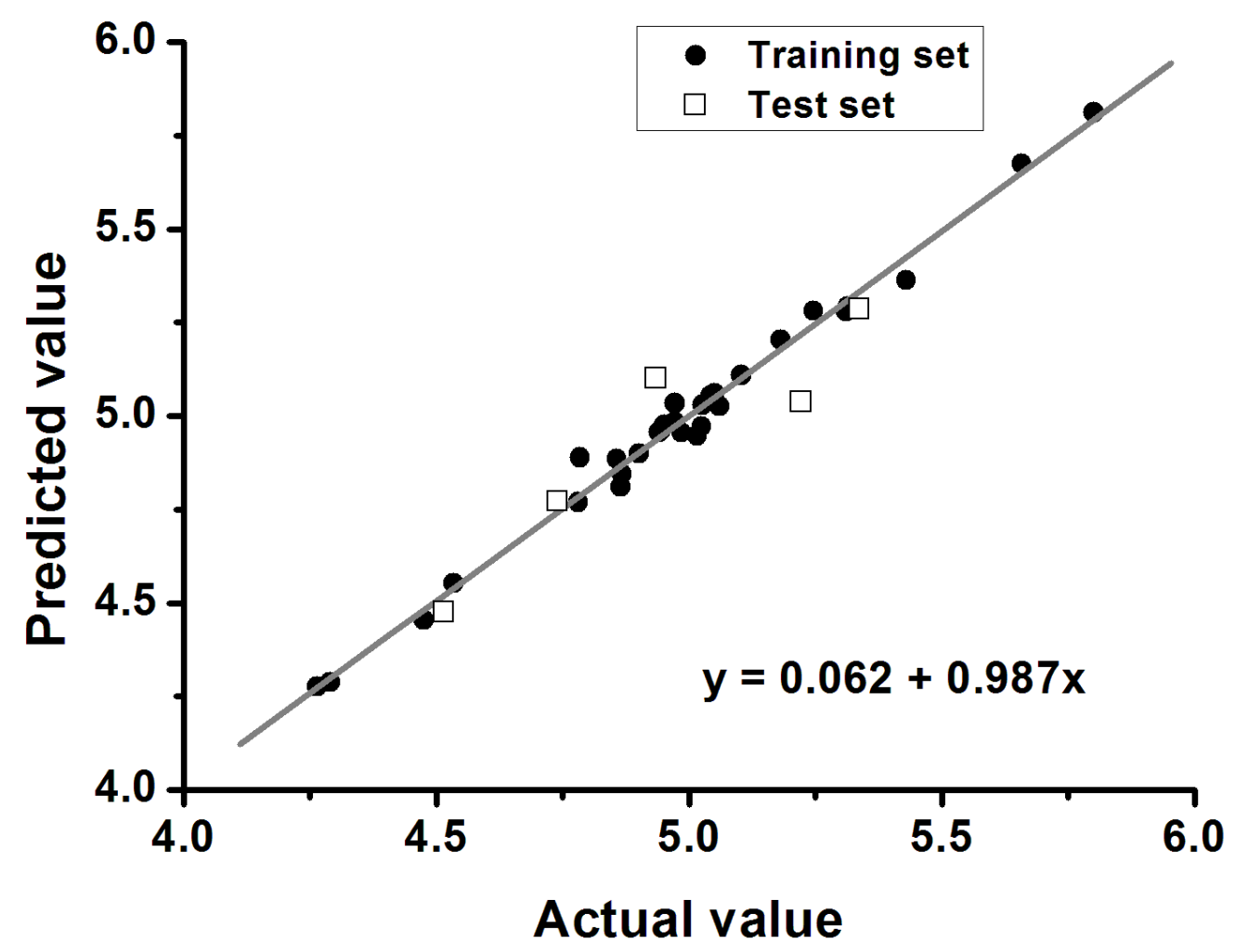

Figure 3. Plot of predicted versus experimental values of the 3D-QSAR CoMSIA model.

To determine how to modify the structure of xyloketal B, we built a model using a series of derivatives to explain the structure-activity relationship. Figure 4 shows a contour map of each field in the presence of xyloketal B. These maps indicated the favorable and unfavorable modification of the compounds in the colored regions. They are (a) an electrostatic map highlighting the regions where electropositive components were favorable (shown in blue) and unfavorable (shown in red) for the activity; (b) a hydrophobic map highlighting the regions where hydrophobic components were favorable (shown in yellow) and unfavorable (shown in white) for the activity; (c) a hydrogen donor map highlighting the regions where hydrogen donor components were favorable (shown in cyan) and unfavorable (shown in purple) for the activity; and (d) a hydrogen acceptor map highlighting the regions where hydrogen donor components were favorable (shown in magenta) and unfavorable (shown in green) for the activity. 

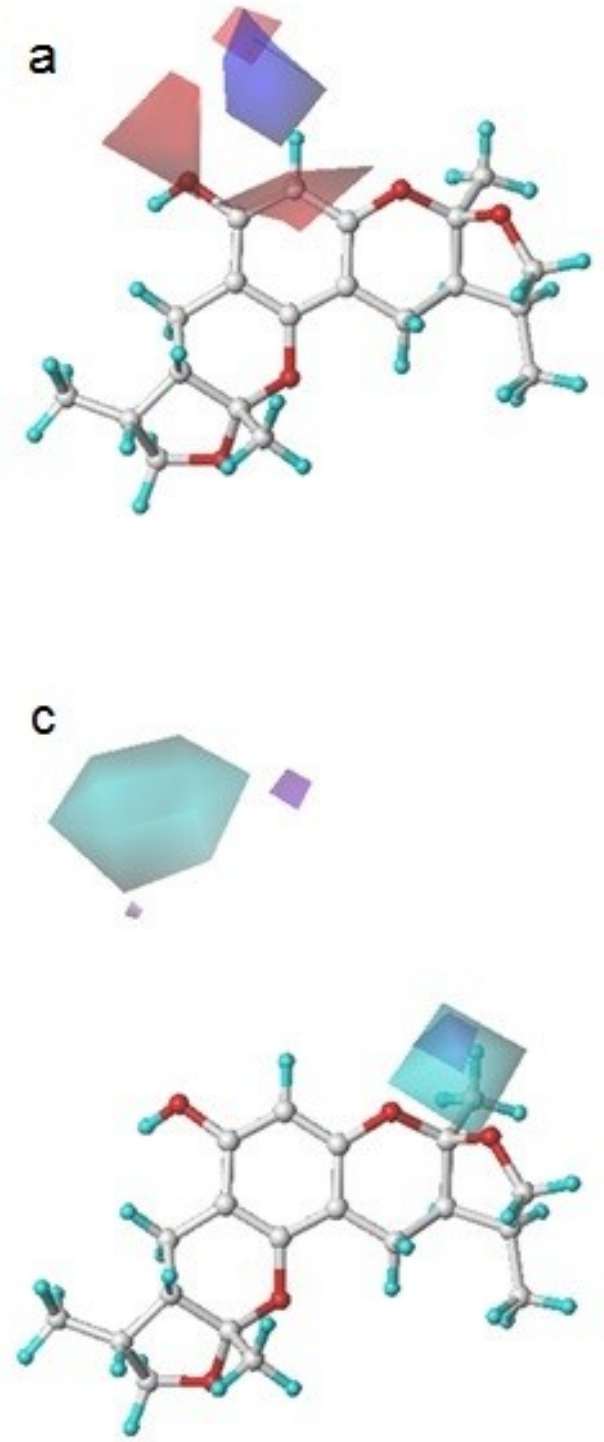

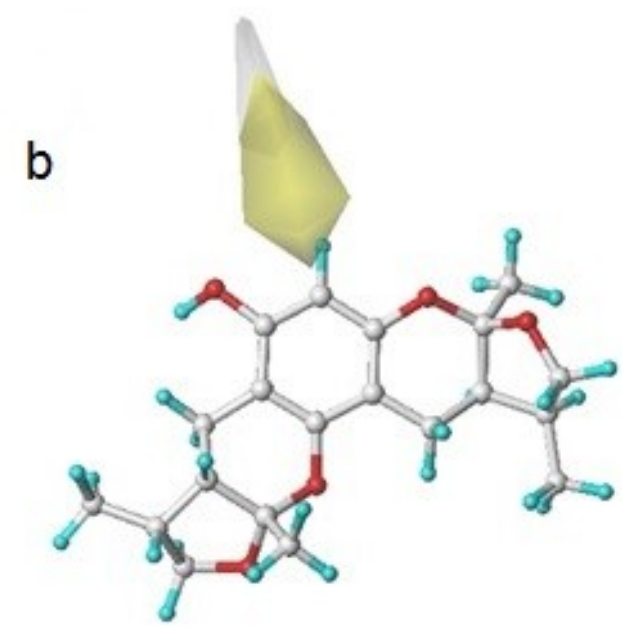

d

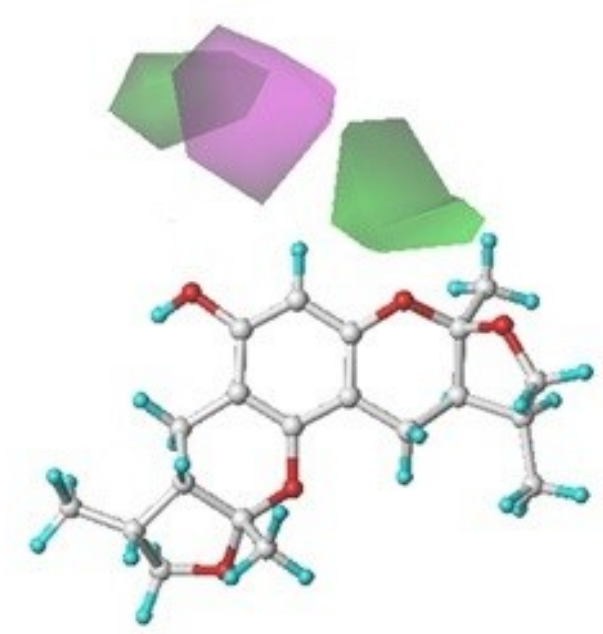

Figure 4. Xyloketal B in CoMSIA contour maps. (a) an electrostatic map: blue and red contour referred to regions where electropositive substituents were favorable and unfavorable for the compound activity; (b) a hydrophobic map: yellow and white contour referred to regions where hydrophobic substituents were favorable and unfavorable for the compound activity; (c) a hydrogen donor map: cyan and purple contour referred to regions where hydrogen donor substituents were favorable and unfavorable for the compound activity; (d) a hydrogen acceptor map: magenta and green contour referred to regions where hydrogen acceptor substituents were favorable and unfavorable for the compound activity.

According to their structural discrepancy, all compounds can be cataloged into three groups. Their common structures are shown in Chart 5. Group A consisted of compounds 1-15 with activities ranging from 15.52 to 55.89. Group B consisted of compounds 16-28, which had activities ranging from 22.97 to 86.34. It contained a unique 6-member ring with different substitution groups. Group $\mathrm{C}$ consisted of compounds 29-35. No drastic modifications were made to these compounds. Therefore, their activities ranged from 52.41 to 72.89 , similar to that of 31-xyloketal B (60.29). 

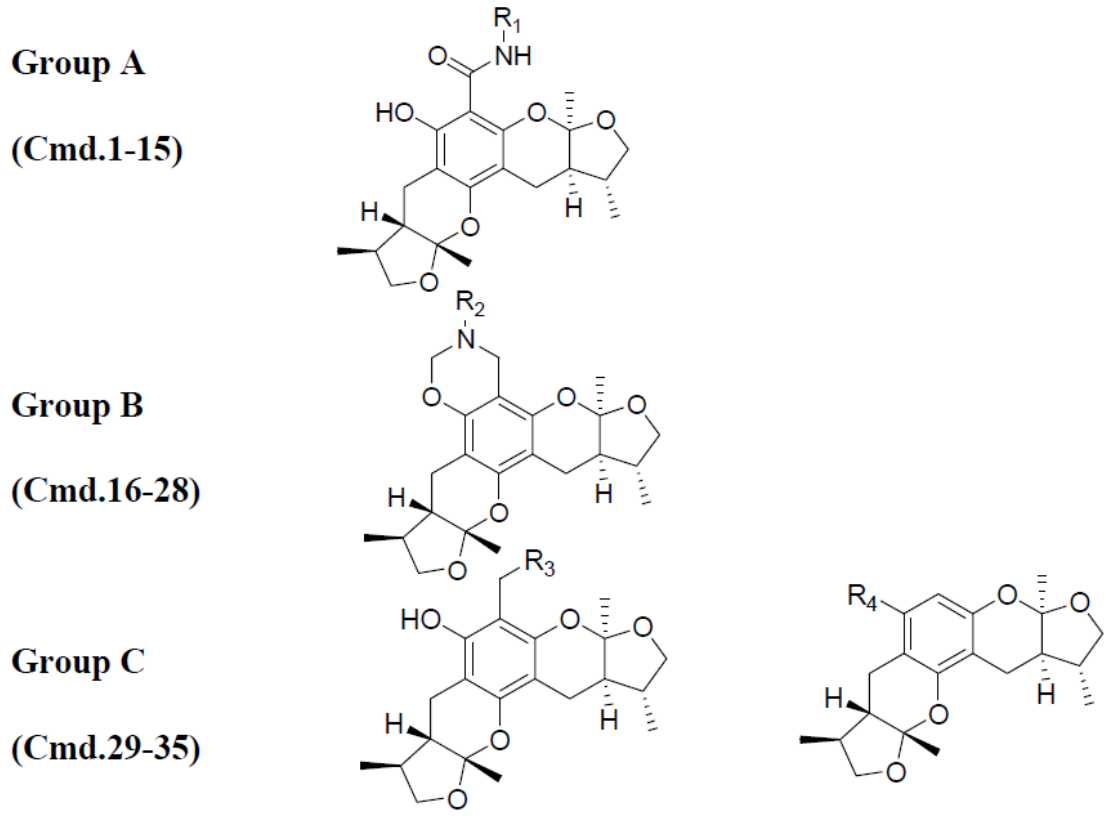

Chart 5. All 35 molecules were divided into three groups based on their structural similarities.

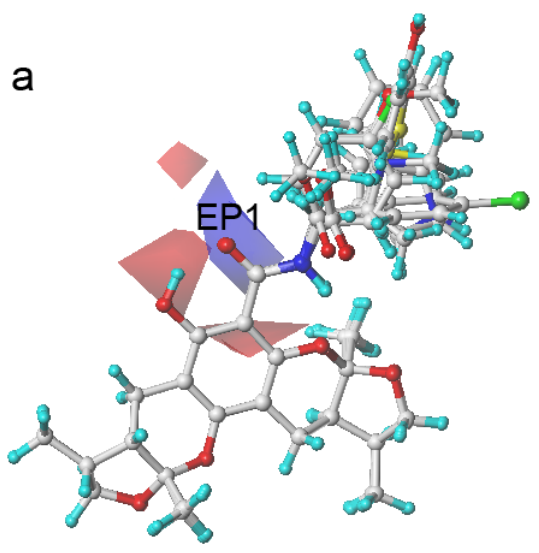

b
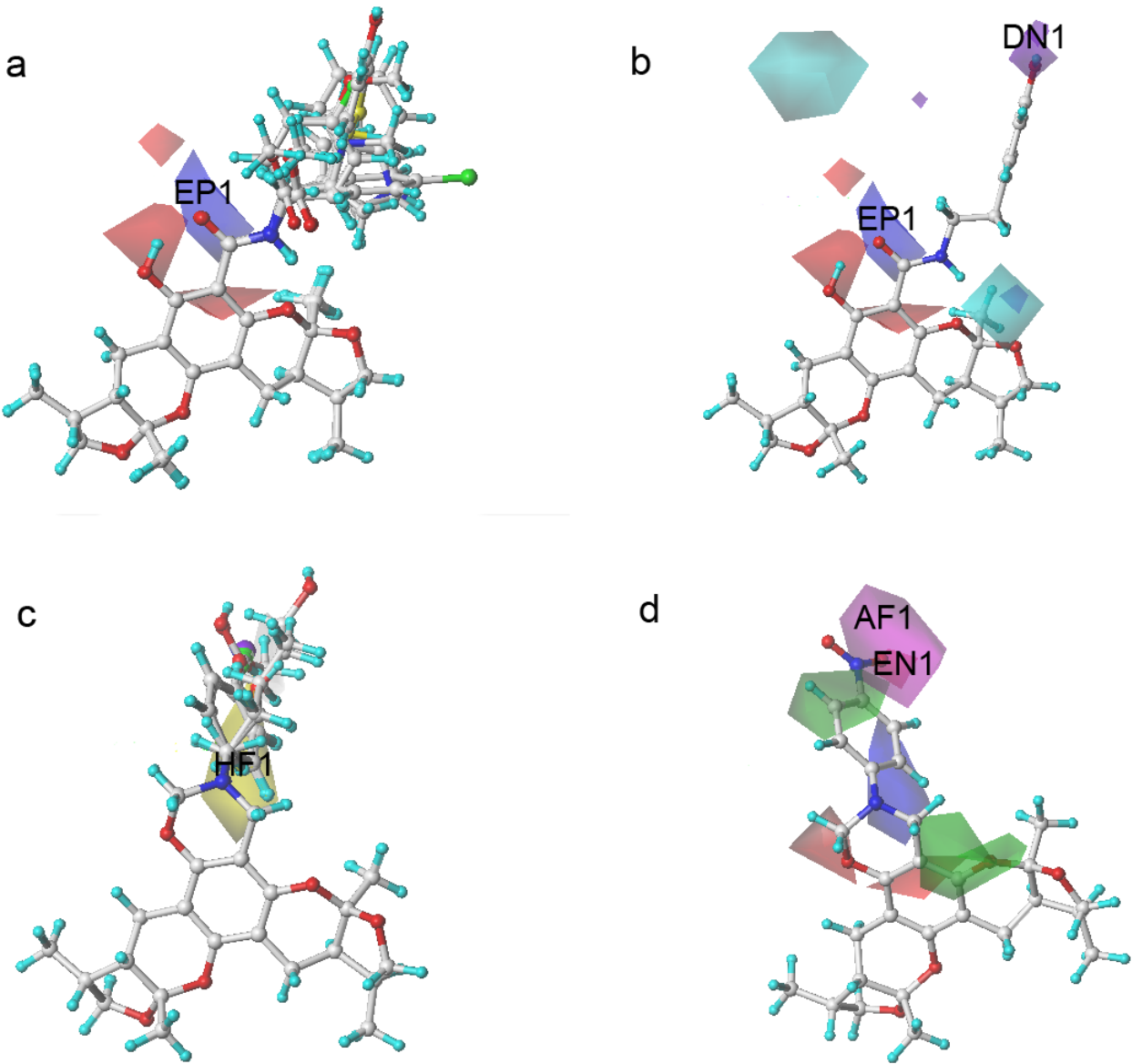

Figure 5. Xyloketal derivatives in CoMSIA contour maps. (a) compounds of Group A overlay with electrostatic maps; $(\mathbf{b})$ compound 5 (cell viability $\%=15.52$ ) with electrostatic and hydrogen donor maps; (c) compounds of Group B overlay with hydrophobic maps; (d) compound 24 (cell viability $\%=86.34$ ) with electrostatic and hydrogen bond acceptor maps. 
The compounds in Group A yielded relatively lower activities. This result could be explained by the mismatch of the CoMSIA force field with the substitution groups. As shown in Figure 5a, the overlay of the compounds in group A had a common amide group, and the oxygen fell into the blue area, EP1. As mentioned previously, the blue contour map indicates areas where positively charged components would increase the activity, but negatively charged components would decrease the activity. Take compound 5 as a more specific example; it not only had the aforementioned common amide group in EP1, but also an -OH group in the purple area DN1. Purple areas indicate that a hydrogen bond donor in the area would have a negative effect on the compound activity (Figure 5b). The above analysis justified why compound 5 had the lowest activity. Some of the compounds in Group B had stronger activities. An overlay of the compounds in Group B in Figure 5c revealed that the substitution groups of compounds in group B took a different orientation to fit in the yellow region HF1. Compound $\mathbf{2 4}$ extended its nitro group into the magenta area AF1 and the red area EN1, where hydrogen bond acceptor and electro-negative groups would elevate the activity of the compound, respectively. Compound $\mathbf{2 4}$ matched the CoMSIA map well (Figure 5d); therefore, it possessed the highest activity of all compounds. In contrast, compounds 25-28 had reduced activities due to replacing the nitro group with halogens, which were not hydrogen bond acceptors. Compounds in Group C produced similar activities to that of xyloketal B because no drastic structural changes were made to these compounds. The substitution groups did not specially fall into regions that increased or decreased the activities.

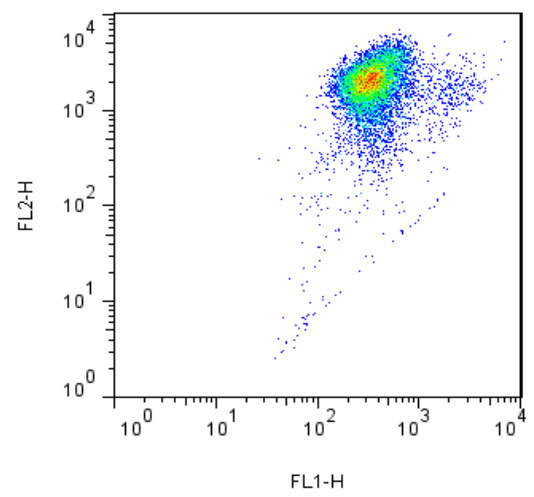

Control

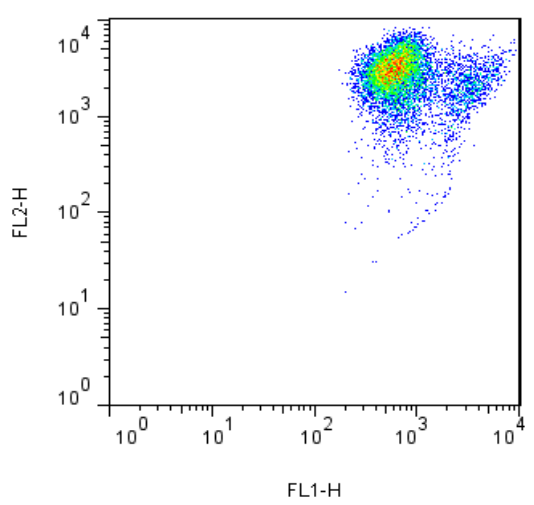

$24(10 \mu \mathrm{M})$

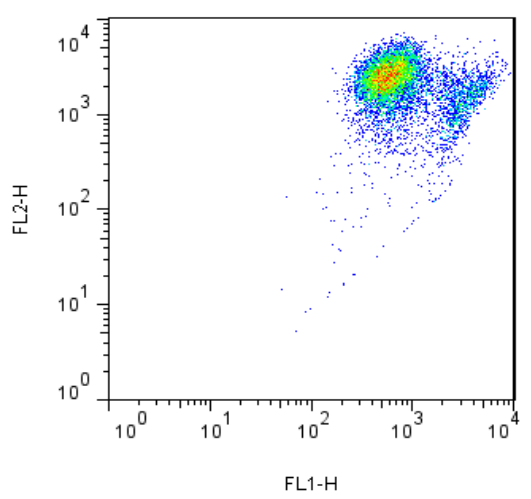

$\mathrm{H}_{2} \mathrm{O}_{2}$ Control

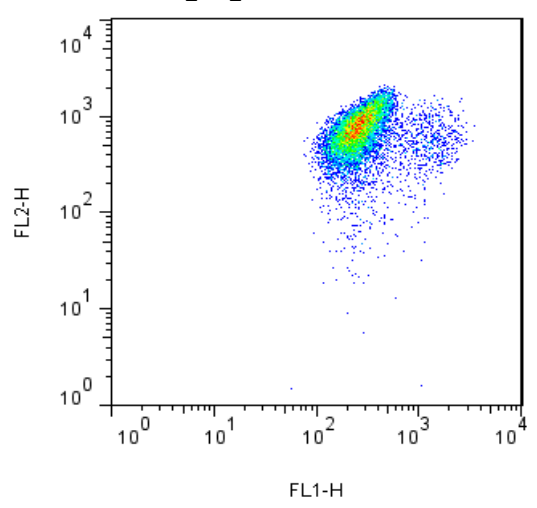

$23(25 \mu \mathrm{M})$
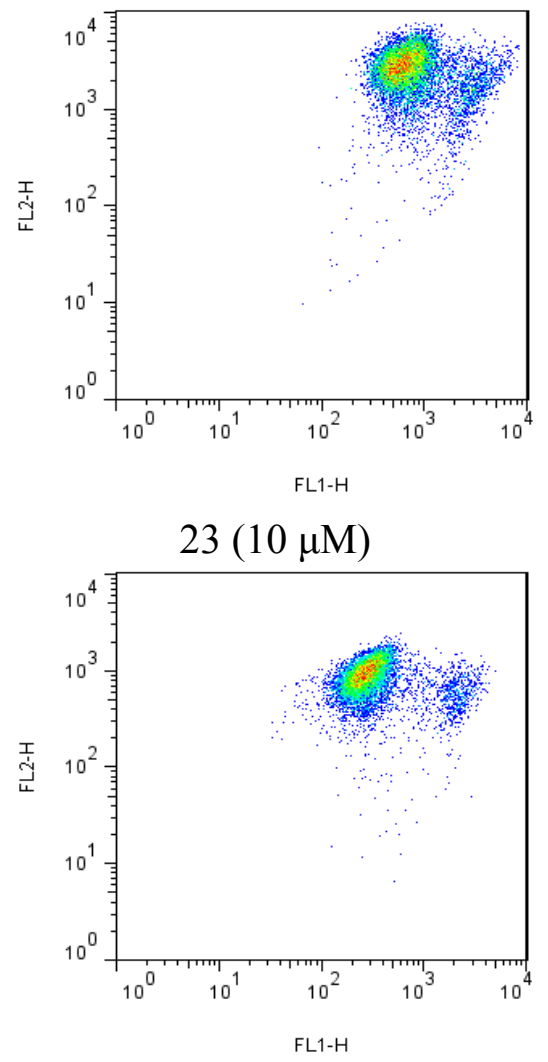

$24(25 \mu \mathrm{M})$

Figure 6. Flow cytometry scatter plot was analyzed using the Flowjo (v7.6.5), showing JC-1 monomers and aggregates in different group. 


\subsection{Xyloketal Derivatives Restored the $\mathrm{H}_{2} \mathrm{O}_{2}$-Induced Reduction of the Mitochondrial Membrane} Potential $(\triangle \Psi m)$

Mitochondria are considered the main source of reactive oxygen species (ROS) in cells. Therefore, we investigated whether xyloketals could protect mitochondria via inhibition of ROS. Compounds $\mathbf{2 3}$ and 24 were examined in the JC-1 mitochondrial membrane potential (MMP) assay of HUVECs using flow cytometry (FCM). As shown in Figures 6 and 7, 23 and 24 significantly inhibited the $\mathrm{H}_{2} \mathrm{O}_{2}$-induced the decrease in the cell mitochondrial membrane potential $(\Delta \Psi \mathrm{m})$ at $25 \mu \mathrm{M}$. Collectively, 23 and 24 effectively protected HUVECs against oxidative damage and further mitochondrial membrane integrity impairment and prevented $\mathrm{H}_{2} \mathrm{O}_{2}$-induced apoptosis of HUVECs by regulating the ROS-mediated mitochondrial dysfunction pathway.

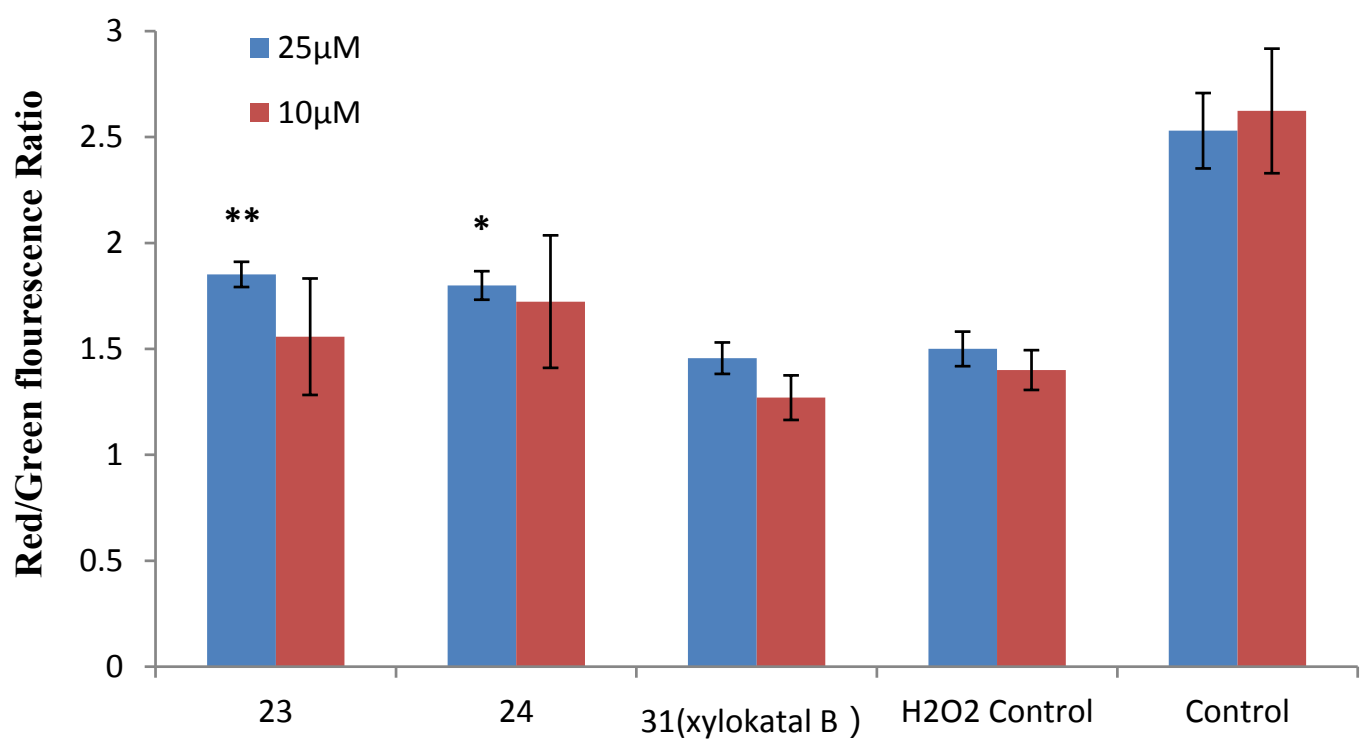

Figure 7. Effects of xyloketal $\mathrm{B}$ and the derivatives $\mathbf{2 3}$ and $\mathbf{2 4}$ on $\mathrm{H}_{2} \mathrm{O}_{2}$-induced decrease of $\triangle \Psi \mathrm{m}$ in HUVECs. HUVECs were pre-incubated with $25 \mu \mathrm{M}$ xyloketal derivatives (blue bars) or $10 \mu \mathrm{M}$ xyloketal derivatives (red bars) for $30 \mathrm{~min}$, and $400 \mu \mathrm{M} \mathrm{H}_{2} \mathrm{O}_{2}$ was added to the medium. After incubation for $20 \mathrm{~h}, \Delta \Psi \mathrm{m}$ was determined by FACS analyses. Values are the mean $\pm \mathrm{SD}(n=6): * p<0.05, * * p<0.01$ versus $\mathrm{H}_{2} \mathrm{O}_{2}$.

\section{Experimental Section}

\subsection{Chemistry}

All reagents and solvents were of commercial quality and used without further purification. ${ }^{1} \mathrm{H}$ and ${ }^{13} \mathrm{C}$ NMR data were recorded on a Bruker AVANCE 400 MB NMR spectrometer (Bruker, Fallanden, Switzerland) operating at 400 and $101 \mathrm{MHz}$ for ${ }^{1} \mathrm{H}$ and ${ }^{13} \mathrm{C}$ respectively. All chemical shifts are in ppm $(\delta)$ with respect to tetramethylsilane (TMS) as internal standard, and coupling constants $(J)$ are in Hz. Mass spectra were obtained on DSQ (low resolution mass spectrometer) (Thermo, San Jose, CA, USA) and MAT95XP (high resolution mass spectrometer) instruments (Thermo, San Jose, CA, USA). 


\subsection{General Procedure of Synthesizing Compounds}

Compound 1. First, $50 \mathrm{mg}(0.13 \mathrm{mmol})$ of xyloketal B acid [16] and $22 \mathrm{mg}(0.20 \mathrm{mmol})$ of $p$-fluoroaniline were dissolved in $10 \mathrm{~mL}$ of DMF in a $50 \mathrm{~mL}$-round-bottom flask. Then, $80 \mathrm{mg}(0.20 \mathrm{mmol})$ of BOP and $0.40 \mathrm{~mL}(2.0 \mathrm{mmol})$ of DIEA were added and stirred at room temperature overnight. The reaction was quenched with $10 \mathrm{~mL}$ saturated solution of ammonium chloride in ice water. The aqueous layer was extracted with ethyl acetate, $3 \times 25 \mathrm{~mL}$. The combined organic extracts were washed with saturated ammonium chloride and brine, dried over anhydrous $\mathrm{MgSO}_{4}$ and concentrated in vacuo. Purification by flash chromatography (petroleum ether: ethyl acetate $=5: 1 \sim 2: 1$ ) gave the title compound. Yield 75\%; white solid; m. p. 68-69 ${ }^{\circ} \mathrm{C} .{ }^{1} \mathrm{H}$ NMR (400 MHz, $\left.\mathrm{CDCl}_{3}\right) \delta 13.97(\mathrm{~s}, 1 \mathrm{H}), 10.59(\mathrm{~s}, 1 \mathrm{H}), 7.57$ $(\mathrm{d}, J=8.4 \mathrm{~Hz}, 2 \mathrm{H}), 7.03(\mathrm{~d}, J=8.4 \mathrm{~Hz}, 2 \mathrm{H}), 4.22-4.15(\mathrm{~m}, 2 \mathrm{H}), 3.53-3.58(\mathrm{~m}, 2 \mathrm{H}), 2.96-2.86(\mathrm{~m}, 2 \mathrm{H})$, 2.73-2.58(m, 2H), 2.14-2.08 (m, 2H), 2.02-1.93 (m, 2H), $1.61(\mathrm{~s}, 3 \mathrm{H}), 1.53(\mathrm{~s}, 3 \mathrm{H}), 1.09$ (d, J=6.0 Hz, $3 \mathrm{H}), 1.07(\mathrm{~d}, J=6.0 \mathrm{~Hz}, 3 \mathrm{H}) .{ }^{13} \mathrm{CNMR}\left(101 \mathrm{MHz}, \mathrm{CDCl}_{3}\right) \delta 168.78 .161 .96,160.64,158.22,155.31$, 150.93, 134.00, 122.44, 115.52, 110.57, 110.31, 108.43, 99.96, 98.40, 96.85, 74.63, 74.25, 47.84, 47.29, 35.68, 35.27, 23.51, 23.02, 18.61, 18.31, 15.89, 15.87. HR-EI-MS $\mathrm{m} / \mathrm{z} 483.2057$; calculated for $\mathrm{C}_{27} \mathrm{H}_{30} \mathrm{FNO}_{6}: 483.2057$.

Compound 2. The title compound was obtained from xyloketal $\mathrm{B}$ acid and $p$-anisidine with a procedure similar to that for compound 1. Yield 73\%; white solid; m. p. 70-71 ${ }^{\circ} \mathrm{C}$. ${ }^{1} \mathrm{H} \mathrm{NMR} \mathrm{(400} \mathrm{MHz,}$ $\left.\mathrm{CDCl}_{3}\right) \delta 14.15(\mathrm{~s}, 1 \mathrm{H}), 10.49(\mathrm{~s}, 1 \mathrm{H}), 7.51(\mathrm{~d}, J=8.8 \mathrm{~Hz}, 2 \mathrm{H}), 6.90(\mathrm{~d}, J=8.8 \mathrm{~Hz}, 2 \mathrm{H}), 4.18(\mathrm{dd}$, $J=8.4 \mathrm{~Hz}, 2 \mathrm{H}), 3.81(\mathrm{~s}, 3 \mathrm{H}), 3.56(\mathrm{dd}, J=8.4 \mathrm{~Hz}, 2 \mathrm{H}), 2.96-2.85(\mathrm{~m}, 2 \mathrm{H}), 2.72-2.58(\mathrm{~m}, 2 \mathrm{H}), 2.16-2.08$ (m, 2H), 2.00-1.93 (m, 2H), $1.62(\mathrm{~s}, 3 \mathrm{H}), 1.52(\mathrm{~s}, 3 \mathrm{H}), 1.08(\mathrm{~d}, J=6.4 \mathrm{~Hz}, 3 \mathrm{H}), 1.07(\mathrm{~d}, J=6.4 \mathrm{~Hz}, 3 \mathrm{H})$. ${ }^{13} \mathrm{C} \mathrm{NMR}\left(101 \mathrm{MHz}, \mathrm{CDCl}_{3}\right) \delta 168.62,161.91,156.51,155.08,151.00,131.05,122.56,114.24,110.42$, $110.17,108.50,108.36,99.89,98.53,97.03,74.55,74.24,55.54,47.77,47.32,35.77,35.28,23.14$, $22.79,18.75,18.34,16.05,15.91$. HR-EI-MS $m / z$ 495.2251; calculated for $\mathrm{C}_{28} \mathrm{H}_{33} \mathrm{NO}_{7}: 495.2257$.

Compound 3. The title compound was obtained from xyloketal B acid and 4-chlorobenzylamine with a procedure similar to that for compound 1. Yield 71\%; white solid; m. p. $72-74{ }^{\circ} \mathrm{C} .{ }^{1} \mathrm{H} \mathrm{NMR}(400 \mathrm{MHz}$, $\left.\mathrm{CDCl}_{3}\right) \delta 14.18(\mathrm{~s}, 1 \mathrm{H}), 8.93(\mathrm{~s}, 1 \mathrm{H}), 7.30(\mathrm{~d}, J=8.4 \mathrm{~Hz}, 2 \mathrm{H}), 7.26(\mathrm{~d}, J=8.4 \mathrm{~Hz}, 2 \mathrm{H}), 4.59(\mathrm{~d}, J=2.0 \mathrm{~Hz}$, $2 \mathrm{H}), 4.20-4.04(\mathrm{~m}, 2 \mathrm{H}), 3.56-3.45(\mathrm{~m}, 2 \mathrm{H}), 2.93-2.82(\mathrm{~m}, 2 \mathrm{H}), 2.70-2.55(\mathrm{~m}, 2 \mathrm{H}), 2.10-2.02(\mathrm{~m}, 2 \mathrm{H})$, 1.96-1.90 (m, 2H), 1.51 (s, 3H), $1.50(\mathrm{~s}, 3 \mathrm{H}), 1.07$ (d, $J=6.4 \mathrm{~Hz}, 3 \mathrm{H}), 1.05(\mathrm{~d}, J=6.4 \mathrm{~Hz}, 3 \mathrm{H}) .{ }^{13} \mathrm{C}$ NMR $\left(101 \mathrm{MHz}, \mathrm{CDCl}_{3}\right) \delta 170.58,161.60,155.01,154.83,151.40,137.06,132.93,128.71,128.54$, 110.05, 109.83, 108.47, 99.70, 98.34, 96.68, 74.41, 74.20, 47.78, 47.37, 42.32, 35.72, 35.29, 23.07, 22.78, 18.69, 18.33, 16.04, 15.89. HR-EI-MS m/z 513.1907; calculated for $\mathrm{C}_{28} \mathrm{H}_{32} \mathrm{ClNO}_{6}: 513.1918$.

Compound 4. The title compound was obtained from xyloketal $\mathrm{B}$ acid and $m$-amino-benzamide with a procedure similar to that for compound 1. Yield 78\%; white solid; m. p. $108-109{ }^{\circ} \mathrm{C}$. ${ }^{1} \mathrm{H}$ NMR $\left(400 \mathrm{MHz}, \mathrm{CDCl}_{3}\right) \delta 13.84(\mathrm{~s}, 1 \mathrm{H}), 10.75(\mathrm{~s}, 1 \mathrm{H}), 8.19(\mathrm{~s}, 1 \mathrm{H}), 7.45(\mathrm{~m}, 3 \mathrm{H}), 5.86(\mathrm{br}, 2 \mathrm{H}), 4.22-4.15$ (m, 2H), 3.59-3.53 (m, 2H), 2.96-2.86 (m, 2H), 2.73-2.60 (m, 2H), 2.15-2.08 (m, 2H), 2.03-1.96 (m, 2H), $1.62(\mathrm{~s}, 3 \mathrm{H}), 1.53(\mathrm{~s}, 3 \mathrm{H}), 1.09$ (d, $J=6.8 \mathrm{~Hz}, 3 \mathrm{H}), 1.07$ (d, $J=6.8 \mathrm{~Hz}, 3 \mathrm{H}) .{ }^{13} \mathrm{C} \mathrm{NMR}(101 \mathrm{MHz}$, $\left.\mathrm{CDCl}_{3}\right) \delta 169.10,169.05,162.01,155.52,150.98,138.32,134.37,129.29,124.14,123.39,119.47$, $110.47,108.49,100.00,98.57,96.83,74.67,74.26,47.86,47.29,35.76,35.26,23.23,23.03,18.71$, 18.37, 16.04, 15.97. HR-EI-MS $m / z$ 508.2201; calculated for $\mathrm{C}_{28} \mathrm{H}_{32} \mathrm{~N}_{2} \mathrm{O}_{7}: 508.2210$. 
Compound 5. The title compound was obtained from xyloketal B acid and tyramine with a procedure similar to that for compound 1. Yield 72\%; white solid; m. p. 97-98 ${ }^{\circ} \mathrm{C} .{ }^{1} \mathrm{H} \mathrm{NMR}\left(400 \mathrm{MHz}, \mathrm{CDCl}_{3}\right) \delta$ $14.43(\mathrm{~s}, 1 \mathrm{H}), 8.56(\mathrm{~s}, 1 \mathrm{H}), 7.08(\mathrm{~d}, J=8.4 \mathrm{~Hz}, 2 \mathrm{H}), 6.76(\mathrm{~d}, J=8.4 \mathrm{~Hz}, 2 \mathrm{H}), 6.19$ (s, 1H), 4.20-4.04 (m, 2H), 3.66-3.58 (m, 2H), 3.56-3.45 (m, 2H), 2.93-2.77 (m, 4H), 2.69-2.52 (m, 2H), 2.10-2.01 (m, 2H), 1.96-1.84 (m, 2H), $1.50(\mathrm{~s}, 3 \mathrm{H}), 1.44(\mathrm{~s}, 3 \mathrm{H}), 1.06(\mathrm{~d}, J=6.4 \mathrm{~Hz}, 3 \mathrm{H}), 1.03$ $(\mathrm{d}, J=6.4 \mathrm{~Hz}, 3 \mathrm{H}) .{ }^{13} \mathrm{C} \mathrm{NMR}\left(101 \mathrm{MHz}, \mathrm{CDCl}_{3}\right) \delta 170.61,161.50,154.68,154.62,151.34,130.72$, $129.83,115.48,109.76,109.55,108.44,108.32$, 99.55, 97.90, 96.72, 74.31, 74.23, 47.62, 47.37, 40.87, $35.46,35.29,34.55,23.02,22.83,18.53,18.35,15.98,15.86$. HR-EI-MS $m / z$ 509.2404; calculated for $\mathrm{C}_{29} \mathrm{H}_{35} \mathrm{NO}_{7}: 509.2414$.

Compound 6. The title compound was obtained from xyloketal B acid and glycine methyl ester hydrochloride with a procedure similar to that for compound 1 . Yield 78\%; white solid; m. p. 75-76 ${ }^{\circ} \mathrm{C}$. ${ }^{1} \mathrm{H}$ NMR (400 MHz, $\left.\mathrm{CDCl}_{3}\right) \delta 13.97$ (s, 1H), 9.03 (s, 1H), 4.28-4.21 (m, 2H), 4.19-4.11 (m, 2H), 3.78 (s, 3H), 3.56-3.48 (m, 2H), 2.91-2.81 (m, 2H), 2.67-2.56 (m, 2H), 2.15-2.04 (m, 2H), 1.96-1.88 (m, 2H), $1.60(\mathrm{~s}, 3 \mathrm{H}), 1.50(\mathrm{~s}, 3 \mathrm{H}), 1.06(\mathrm{~d}, J=6.4 \mathrm{~Hz}, 3 \mathrm{H}), 1.04(\mathrm{~d}, J=6.4 \mathrm{~Hz}, 3 \mathrm{H}) .{ }^{13} \mathrm{C} \mathrm{NMR}(101 \mathrm{MHz}$, $\left.\mathrm{CDCl}_{3}\right) \delta 170.57,170.12,161.48,154.93,151.52,109.75,108.40,99.66,98.28,96.51,74.41,74.17$, $52.28,47.76,47.27,41.31,35.70,35.22,22.96,22.75,18.60,18.30,16.04,15.85$. HR-EI-MS $\mathrm{m} / \mathrm{z}$ 461.2043; calculated for $\mathrm{C}_{24} \mathrm{H}_{31} \mathrm{NO}_{8}: 461.2050$.

Compound 7. The title compound was obtained from xyloketal B acid and valine methyl ester hydrochloride with a procedure similar to that for compound 1 . Yield $76 \%$; white solid; m. p. $80-81{ }^{\circ} \mathrm{C}$. ${ }^{1} \mathrm{H}$ NMR (400 MHz, $\left.\mathrm{CDCl}_{3}\right) \delta 14.08(\mathrm{~s}, 1 \mathrm{H}), 9.17(\mathrm{~s}, 1 \mathrm{H}), 4.68-4.62(\mathrm{~m}, 1 \mathrm{H}), 4.25-4.08(\mathrm{~m}, 2 \mathrm{H}), 3.77$ (s, 3H), 3.59-3.51 (m, 2H), 2.94-2.86 (m, 2H), 2.70-2.57 (m, 2H), 2.34-2.28 (m, 1H), 2.22-2.07 (m, 2H), 2.01-1.93 (m, 2H), $1.62(\mathrm{~s}, 3 \mathrm{H}), 1.54(\mathrm{~s}, 3 \mathrm{H}), 1.09(\mathrm{~d}, J=6.4 \mathrm{~Hz}, 3 \mathrm{H}), 1.07$ (d, $J=6.4 \mathrm{~Hz}, 3 \mathrm{H}), 1.04$ (d, $J=6.8 \mathrm{~Hz}, 6 \mathrm{H}) .{ }^{13} \mathrm{C} \mathrm{NMR}\left(101 \mathrm{MHz}, \mathrm{CDCl}_{3}\right) \delta 172.19,170.47,161.57,154.90,151.53,109.73,108.42$, 99.49, 98.22, 96.62, 77.02, 74.37, 74.26, 57.23, 52.04, 47.53, 47.33, 35.27, 30.92, 23.20, 23.01, 22.76, 19.22, 18.66, 18.36, 17.54, 16.23, 15.88. HR-EI-MS $m / z$ 503.2515; calculated for $\mathrm{C}_{27} \mathrm{H}_{37} \mathrm{NO}_{8}$ : 503.2519.

Compound 8. The title compound was obtained from xyloketal $\mathrm{B}$ acid and tyrosine methyl ester hydrochloride with a procedure similar to that for compound 1 . Yield $75 \%$; white solid; m. p. 95-95 ${ }^{\circ} \mathrm{C}$. ${ }^{1} \mathrm{H}$ NMR $\left(400 \mathrm{MHz}, \mathrm{CDCl}_{3}\right) \delta 14.06(\mathrm{~s}, 1 \mathrm{H}), 9.01(\mathrm{~s}, 1 \mathrm{H}), 7.04(\mathrm{~d}, J=8.0 \mathrm{~Hz}, 2 \mathrm{H}), 6.71(\mathrm{~d}, J=8.0 \mathrm{~Hz}$, 2H), $5.5(\mathrm{br}, 1 \mathrm{H}), 4.92-4.87(\mathrm{~m}, 1 \mathrm{H}), 4.22-3.97(\mathrm{~m}, 2 \mathrm{H}), 3.72(\mathrm{~s}, 3 \mathrm{H}), 3.57-3.48(\mathrm{~m}, 2 \mathrm{H}), 3.21-3.15(\mathrm{~m}$, $1 \mathrm{H}), 3.04(\mathrm{~d}, J=6.8 \mathrm{~Hz}, 1 \mathrm{H}), 2.90-2.77(\mathrm{~m}, 2 \mathrm{H}), 2.66-2.53(\mathrm{~m}, 2 \mathrm{H}), 2.11-2.02(\mathrm{~m}, 2 \mathrm{H}), 1.96-1.85(\mathrm{~m}$, 2H), 1.51 (s, 3H), 1.39 (s, 3H), $1.06(\mathrm{~d}, J=6.4 \mathrm{~Hz}, 3 \mathrm{H}), 0.98$ (d, $J=6.4 \mathrm{~Hz}, 3 \mathrm{H}) .{ }^{13} \mathrm{C}$ NMR $(101 \mathrm{MHz}$, $\left.\mathrm{CDCl}_{3}\right) \delta 171.99,170.10,161.58,154.98,154.82,151.63,130.48,128.23,115.46,109.82,109.59$, 108.44, 108.33, 99.34, 97.83, 96.40, 74.25, 74.09, 54.13, 52.29, 47.56, 47.29, 37.24, 35.23, 23.04, 22.79, 19.16, 18.72, 18.30, 16.16, 15.99. HR-EI-MS $m / z$ 567.2465; calculated for $\mathrm{C}_{31} \mathrm{H}_{37} \mathrm{NO}_{9}: 567.2468$.

Compound 9. The title compound was obtained from xyloketal B acid and cysteamine with a procedure similar to that for compound 1. Yield 73\%; white solid; m. p. $72-73{ }^{\circ} \mathrm{C}$. ${ }^{1} \mathrm{H} \mathrm{NMR}(400 \mathrm{MHz}$, $\left.\mathrm{CDCl}_{3}\right) \delta 14.26(\mathrm{~s}, 1 \mathrm{H}), 8.84(\mathrm{~s}, 1 \mathrm{H}), 4.21-4.13(\mathrm{~m}, 2 \mathrm{H}), 3.80-3.70(\mathrm{~m}, 2 \mathrm{H}), 3.57-3.48(\mathrm{~m}, 2 \mathrm{H}), 2.90(\mathrm{t}$, $J=6.4 \mathrm{~Hz}, 2 \mathrm{H}), 2.86-2.80(\mathrm{~m}, 2 \mathrm{H}), 2.70-2.56(\mathrm{~m}, 2 \mathrm{H}), 2.11-2.03(\mathrm{~m}, 2 \mathrm{H}), 1.97-1.90(\mathrm{~m}, 2 \mathrm{H}), 1.67$ (br, $1 \mathrm{H}), 1.55(\mathrm{~s}, 3 \mathrm{H}), 1.51(\mathrm{~s}, 3 \mathrm{H}), 1.07(\mathrm{~d}, J=6.4 \mathrm{~Hz}, 3 \mathrm{H}), 1.04(\mathrm{~d}, J=6.4 \mathrm{~Hz}, 3 \mathrm{H}) .{ }^{13} \mathrm{C} \mathrm{NMR}(101 \mathrm{MHz}$, $\left.\mathrm{CDCl}_{3}\right) \delta 170.72,161.59,154.98,151.45,109.66,108.27,99.47,97.80,96.64,74.42,74.22,47.65$, 
47.33, 38.06, 37.76, 35.62, 35.25, 23.22, 22.93, 18.60, 18.31, 16.04, 15.90. HR-EI-MS m/z 449.1869; calculated for $\mathrm{C}_{23} \mathrm{H}_{31} \mathrm{NO}_{6} \mathrm{~S}$ : 449.1872 .

Compound 10. The title compound was obtained from xyloketal $\mathrm{B}$ acid and $N, N$-dimethyl ethylenediamine with a procedure similar to that for compound 1 . Yield $70 \%$; white solid; m. p. $71-72{ }^{\circ} \mathrm{C}$. ${ }^{1} \mathrm{H}$ NMR (400 MHz, $\left.\mathrm{CDCl}_{3}\right) \delta 13.49(\mathrm{~s}, 1 \mathrm{H}), 8.94(\mathrm{~s}, 1 \mathrm{H}), 4.17$ (dd, $\left.J=16.4,6.8 \mathrm{~Hz}, 2 \mathrm{H}\right)$, $3.75-3.65(\mathrm{~m}, 2 \mathrm{H}), 3.52(\mathrm{q}, J=6.8 \mathrm{~Hz}, 2 \mathrm{H}), 3.27(\mathrm{t}, J=5.6 \mathrm{~Hz}, 2 \mathrm{H}), 2.91(\mathrm{~s}, 6 \mathrm{H}), 2.82(\mathrm{~d}, J=6.8 \mathrm{~Hz}$, 2H), 2.60-2.49 (m, 2H), 2.07-2.01 (m, 2H), 1.96-1.88 (m, 2H), $1.53(\mathrm{~s}, 3 \mathrm{H}), 1.50(\mathrm{~s}, 3 \mathrm{H}), 1.06$ $(\mathrm{d}, J=6.8 \mathrm{~Hz}, 3 \mathrm{H}), 1.02(\mathrm{~d}, J=6.8 \mathrm{~Hz}, 3 \mathrm{H}) .{ }^{13} \mathrm{C} \mathrm{NMR}\left(101 \mathrm{MHz}, \mathrm{CDCl}_{3}\right) \delta 172.26,161.34,155.71$, 151.49, 110.03, 108.58, 99.59, 98.46, 95.89, 74.37, 74.18, 59.20, 47.46, 47.18, 44.18, 36.69, 36.01, $35.40,23.04,22.75,18.36,18.25,15.95,15.81,15.68$. HR-EI-MS $\mathrm{m} / z$ 460.2563; calculated for $\mathrm{C}_{25} \mathrm{H}_{36} \mathrm{~N}_{2} \mathrm{O}_{6}: 460.2573$.

Compound 11. The title compound was obtained from xyloketal B acid and thiophene ethylamine with a procedure similar to that for compound 1 . Yield $76 \%$; white solid; m. p. $75-76{ }^{\circ} \mathrm{C}$. ${ }^{1} \mathrm{H}$ NMR $\left(400 \mathrm{MHz}, \mathrm{CDCl}_{3}\right) \delta 14.41(\mathrm{~s}, 1 \mathrm{H}), 8.66(\mathrm{~s}, 1 \mathrm{H}), 7.14(\mathrm{~d}, J=5.2 \mathrm{~Hz}, 1 \mathrm{H}), 6.92(\mathrm{~d}, J=5.2 \mathrm{~Hz}, 1 \mathrm{H})$, 6.90-6.89 (m, 1H), 4.25 (dd, $J=16.4,6.8 \mathrm{~Hz}, 2 \mathrm{H}), 3.76-3.63(\mathrm{~m}, 2 \mathrm{H}), 3.56-3.45$ (m, 2H), 3.13 $(\mathrm{t}, J=6.8 \mathrm{~Hz}, 2 \mathrm{H}), 2.93-2.79(\mathrm{~m}, 2 \mathrm{H}), 2.69-2.53(\mathrm{~m}, 2 \mathrm{H}), 2.11-2.00(\mathrm{~m}, 2 \mathrm{H}), 1.97-1.86(\mathrm{~m}, 2 \mathrm{H}), 1.51$ $(\mathrm{s}, 3 \mathrm{H}), 1.42(\mathrm{~s}, 3 \mathrm{H}), 1.07(\mathrm{~d}, J=6.4 \mathrm{~Hz}, 3 \mathrm{H}), 1.03(\mathrm{~d}, J=6.4 \mathrm{~Hz}, 3 \mathrm{H}) .{ }^{13} \mathrm{C} \mathrm{NMR}\left(101 \mathrm{MHz}, \mathrm{CDCl}_{3}\right)$ $\delta 170.67,161.65,154.67,151.35,141.59,126.94,125.34,123.73,109.46,108.37,99.45,97.56,96.64$, 74.34, 74.21, 47.56, 47.34, 40.70, 35.53, 35.26, 29.80, 22.97, 22.68, 18.67, 18.38, 16.06, 15.91. HR-EI-MS m/z 499.2025; calculated for $\mathrm{C}_{27} \mathrm{H}_{33} \mathrm{NO}_{6} \mathrm{~S}$ : 499.2029.

Compound 12. The title compound was obtained from xyloketal B acid and phenylalanine methyl ester hydrochloride with a procedure similar to that for compound 1. Yield 73\%; white solid; m. p. 72-73 ${ }^{\circ} \mathrm{C} .{ }^{1} \mathrm{H}$ NMR $\left(400 \mathrm{MHz}, \mathrm{CDCl}_{3}\right) \delta 14.05(\mathrm{~s}, 1 \mathrm{H}), 9.03(\mathrm{~s}, 1 \mathrm{H}), 7.27-7.20(\mathrm{~m}, 5 \mathrm{H})$, 5.00-4.95 (m, 1H), 4.21-4.15 (m, 2H), $3.74(\mathrm{~s}, 3 \mathrm{H}), 3.59-3.50(\mathrm{~m}, 2 \mathrm{H}), 3.32-3.26(\mathrm{~m}, 1 \mathrm{H}), 3.14$ $(\mathrm{d}, J=7.2 \mathrm{~Hz}, 1 \mathrm{H}), 2.93-2.80(\mathrm{~m}, 2 \mathrm{H}), 2.73-2.54(\mathrm{~m}, 2 \mathrm{H}), 2.11-2.05(\mathrm{~m}, 2 \mathrm{H}), 1.97-1.90(\mathrm{~m}, 2 \mathrm{H}), 1.52$ $(\mathrm{s}, 3 \mathrm{H}), 1.38(\mathrm{~s}, 3 \mathrm{H}), 1.08(\mathrm{~d}, J=6.4 \mathrm{~Hz}, 3 \mathrm{H}), 1.05(\mathrm{~d}, J=6.4 \mathrm{~Hz}, 3 \mathrm{H}) .{ }^{13} \mathrm{C}$ NMR $(101 \mathrm{MHz}, \mathrm{CDCl} 3) \delta$ 171.71, 170.14, 161.63, 154.96, 151.66, 136.47, 129.31, 128.49, 128.39, 126.79, 109.78, 109.57, 108.41, $99.34,97.89,96.42,74.30,74.18,53.77,52.16,47.62,47.37,38.04,35.66,22.93,22.66,18.71,18.64$, 18.28, 16.04, 15.87. HR-EI-MS $m / z$ 551.2512; calculated for $\mathrm{C}_{31} \mathrm{H}_{37} \mathrm{NO}_{8}: 551.2519$.

Compound 13. The title compound was obtained from xyloketal B acid and tryptophan methyl hydrochloride with a procedure similar to that for compound 1 . Yield $72 \%$; white solid; m. p. $110-111^{\circ} \mathrm{C}$. ${ }^{1} \mathrm{H}$ NMR (400 MHz, $\left.\mathrm{CDCl}_{3}\right) \delta 14.14(\mathrm{~s}, 1 \mathrm{H}), 9.03(\mathrm{~s}, 1 \mathrm{H}), 8.19(\mathrm{~s}, 1 \mathrm{H}), 7.55(\mathrm{t}, J=8.0 \mathrm{~Hz}, 1 \mathrm{H}), 7.30(\mathrm{~d}$, $J=8.0 \mathrm{~Hz}, 1 \mathrm{H}), 7.17(\mathrm{~s}, 1 \mathrm{H}), 7.13-7.11(\mathrm{~m}, 1 \mathrm{H}), 7.06-7.00(\mathrm{~m}, 1 \mathrm{H}), 5.10-4.99(\mathrm{~m}, 1 \mathrm{H}), 4.15(\mathrm{dd}$, $J=16.4,6.8 \mathrm{~Hz}, 2 \mathrm{H}), 3.67(\mathrm{~s}, 3 \mathrm{H}), 3.57-3.45(\mathrm{~m}, 2 \mathrm{H}), 3.40-3.29(\mathrm{~m}, 2 \mathrm{H}), 2.92-2.77(\mathrm{~m}, 2 \mathrm{H})$, 2.70-2.55 (m, 2H), 2.11-2.01 (m, 2H), 1.89-1.82 (m, 2H), $1.52(\mathrm{~s}, 3 \mathrm{H}), 1.48(\mathrm{~s}, 3 \mathrm{H}), 1.06$ $(\mathrm{d}, J=6.4 \mathrm{~Hz}, 3 \mathrm{H}), 1.02(\mathrm{~d}, J=6.4 \mathrm{~Hz}, 3 \mathrm{H}) .{ }^{13} \mathrm{C} \mathrm{NMR}\left(101 \mathrm{MHz}, \mathrm{CDCl}_{3}\right) \delta 172.18,170.12,161.56$, $154.99,151.52,136.11,127.63,123.18,121.81,119.42,118.75,110.95,110.20,109.54,108.34,99.26$, 97.71, 96.46, 74.18, 74.00, 53.34, 52.19, 47.43, 47.24, 35.44, 35.15, 27.72, 22.91, 22.71, 22.40, 18.64, 18.26, 15.82. HR-EI-MS m/z 590.2623; calculated for $\mathrm{C}_{33} \mathrm{H}_{38} \mathrm{~N}_{2} \mathrm{O}_{8}: 590.2628$. 
Compound 16. First, $50 \mathrm{mg}(0.14 \mathrm{mmol})$ of xyloketal $\mathrm{B}$ [16] and $8.7 \mathrm{mg}(0.28 \mathrm{mmol})$ of methylamine were dissolved in $10 \mathrm{~mL}$ of DMF and stirred, followed by adding $0.05 \mathrm{~mL}(0.28 \mathrm{mmol})$ of $40 \%$ formaldehyde solution, stirred at room temperature for $1 \mathrm{~h}$. The reaction was quenched with water. The aqueous layer was extracted with ethyl acetate, $3 \times 25 \mathrm{~mL}$. The combined organic extracts were washed with saturated ammonium chloride and brine, dried over anhydrous $\mathrm{MgSO}_{4}$ and concentrated in vacuo. Purification by flash chromatography (petroleum ether: ethyl acetate $=5: 1 \sim 2: 1$ ) gave the title compound. Yield 89\%; white solid; m. p. $62-63{ }^{\circ} \mathrm{C} .{ }^{1} \mathrm{H}$ NMR $\left(400 \mathrm{MHz}, \mathrm{CDCl}_{3}\right) \delta 4.66(\mathrm{~s}, 2 \mathrm{H}), 4.15-4.08(\mathrm{~m}, 2 \mathrm{H})$, $3.75(\mathrm{~s}, 2 \mathrm{H}), 3.49(\mathrm{t}, J=8.4 \mathrm{~Hz}, 2 \mathrm{H}), 2.79(\mathrm{dt}, J=17.25 .2 \mathrm{~Hz}, 2 \mathrm{H}), 2.60(\mathrm{~d}, J=17.2 \mathrm{~Hz}, 2 \mathrm{H}), 2.53$ (s, 3H), 2.11-2.04 (m, 2H), 1.87-1.81 (m, 2H), 1.47 (s, 3H), $1.44(\mathrm{~s}, 3 \mathrm{H}), 1.04$ (d, J=6.4 Hz, 3H), 1.01 (d, $J=6.4 \mathrm{~Hz}, 3 \mathrm{H}) ;{ }^{13} \mathrm{C} \mathrm{NMR}\left(101 \mathrm{MHz}, \mathrm{CDCl}_{3}\right): \delta 150.13,149.50,148.87,107.25,107.14,100.01,98.73$, $98.12,83.58,73.85,47.33,47.47,40.03,35.42,35.32,22.98,22.72,18.73,18.39,16.07,15.99$. HR-EIMS $m / z$ 401.2196; calculated for $\mathrm{C}_{23} \mathrm{H}_{31} \mathrm{O}_{5} \mathrm{~N}_{1}$ : 401.2197 .

Compound 17. The title compound was obtained from xyloketal $\mathrm{B}$ and butylamine with a procedure similar to that for compound 16. Yield 93\%; white solid; m. p. $65-66{ }^{\circ} \mathrm{C} .{ }^{1} \mathrm{H}$ NMR $\left(400 \mathrm{MHz}, \mathrm{CDCl}_{3}\right)$ $\delta 4.76(\mathrm{~s}, 2 \mathrm{H}), 4.20-4.12(\mathrm{~m}, 2 \mathrm{H}), 3.82(\mathrm{~s}, 2 \mathrm{H}), 3.52(\mathrm{t}, J=8.4 \mathrm{~Hz}, 2 \mathrm{H}), 2.86-2.80(\mathrm{~m}, 2 \mathrm{H}), 2.69(\mathrm{t}$, $J=17.2 \mathrm{~Hz}, 2 \mathrm{H}), 2.67-2.59(\mathrm{~m}, 2 \mathrm{H}), 2.17-2.11(\mathrm{~m}, 2 \mathrm{H}), 1.91-1.83(\mathrm{~m}, 2 \mathrm{H}), 1.58-1.51(\mathrm{~m}, 2 \mathrm{H}), 1.49$ $(\mathrm{s}, 3 \mathrm{H}), 1.48(\mathrm{~s}, 3 \mathrm{H}), 1.00-1.30(\mathrm{~m}, 2 \mathrm{H}), 1.06(\mathrm{~d}, J=6.4 \mathrm{~Hz}, 3 \mathrm{H}), 1.03(\mathrm{~d}, J=6.4 \mathrm{~Hz}, 3 \mathrm{H}), 0.92(\mathrm{t}$, $J=7.6 \mathrm{~Hz}, 3 \mathrm{H}) ;{ }^{13} \mathrm{C} \mathrm{NMR}\left(101 \mathrm{MHz}, \mathrm{CDCl}_{3}\right) \delta 150.75,149.40,148.95,107.33,107.24,100.49,98.72$, $98.25,82.68,73.96,51.64,47.59,47.59,45.91,35.55,35.44,30.29,23.06,22.79,20.48,18.85,18.506$, 16.081, 16.00, 14.05. HR-EI-MS $m / z$ 443.2665; calculated for $\mathrm{C}_{26} \mathrm{H}_{37} \mathrm{O}_{5} \mathrm{~N}_{1}: 443.2666$.

Compound 18. The title compound was obtained from xyloketal $\mathrm{B}$ and ethanolamine with a procedure similar to that for compound 16. Yield 79\%; white solid; m. p. $112-113{ }^{\circ} \mathrm{C}$. ${ }^{1} \mathrm{H} \mathrm{NMR}\left(400 \mathrm{MHz}, \mathrm{CDCl}_{3}\right)$ $\delta 4.80(\mathrm{~s}, 2 \mathrm{H}), 4.2(\mathrm{~s}, 1 \mathrm{H}), 4.16(\mathrm{dd}, J=16.4,6.4 \mathrm{~Hz}, 2 \mathrm{H}), 3.86(\mathrm{~s}, 2 \mathrm{H}), 3.68(\mathrm{t}, J=5.2 \mathrm{~Hz}, 2 \mathrm{H})$, 3.54-3.47 (m, 2H), 2.92-2.89 (m, 2H), 2.86-2.75 (m, 2H), 2.66-2.59 (m, 2H), 2.15-2.07 (m, 2H), 1.91-1.82 (m, 2H), $1.49(\mathrm{~s}, 3 \mathrm{H}), 1.47(\mathrm{~s}, 3 \mathrm{H}), 1.06(\mathrm{~d}, J=6.4 \mathrm{~Hz}, 3 \mathrm{H}), 1.03(\mathrm{~d}, J=6.4 \mathrm{~Hz}, 3 \mathrm{H})$;

${ }^{13} \mathrm{C} \mathrm{NMR}\left(\mathrm{CDCl}_{3}, 101 \mathrm{MHz}\right) \delta 150.55,149.64,148.83,107.27,99.91,98.82,98.21,82.79,73.90,59.02$, 53.77, 47.36, 47.26, 45.39, 35.31, 22.93, 22.67, 18.63, 18.38, 15.95. HR-EI-MS m/z 431.2301; calculated for $\mathrm{C}_{24} \mathrm{H}_{33} \mathrm{O}_{6} \mathrm{~N}_{1}: 431.2302$.

Compound 19. The title compound was obtained from xyloketal $\mathrm{B}$ and diglycolamine with a procedure similar to that for compound 16. Yield $72 \%$; white solid; m. p. $126-127{ }^{\circ} \mathrm{C}$. ${ }^{1} \mathrm{H} \mathrm{NMR}\left(400 \mathrm{MHz}, \mathrm{CDCl}_{3}\right)$ $\delta 4.82$ (s, 2H), 4.14 (dd, $J=16.4,6.4 \mathrm{~Hz}, 2 \mathrm{H}), 3.89$ (s, 2H), 3.73 (t, $J=5.2 \mathrm{~Hz}, 2 \mathrm{H}), 3.68$ (t, $J=5.2 \mathrm{~Hz}$, $2 \mathrm{H}), 3.61(\mathrm{t}, J=5.2 \mathrm{~Hz}, 2 \mathrm{H}), 3.55-3.48(\mathrm{~m}, 2 \mathrm{H}), 2.97(\mathrm{br}, 1 \mathrm{H}), 2.95-2.90(\mathrm{~m}, 2 \mathrm{H}), 2.86-2.75(\mathrm{~m}, 2 \mathrm{H})$, $2.62(\mathrm{t}, J=5.6 \mathrm{~Hz}, 2 \mathrm{H}), 2.16-2.06(\mathrm{~m}, 2 \mathrm{H}), 1.91-1.84(\mathrm{~m}, 2 \mathrm{H}), 1.50(\mathrm{~s}, 3 \mathrm{H}), 1.47(\mathrm{~s}, 3 \mathrm{H}), 1.06(\mathrm{~d}$, $J=6.4 \mathrm{~Hz}, 3 \mathrm{H}), 1.03(\mathrm{~d}, J=6.4 \mathrm{~Hz}, 3 \mathrm{H}) ;{ }^{13} \mathrm{C} \mathrm{NMR}\left(101 \mathrm{MHz}, \mathrm{CDCl}_{3}\right) \delta 150.55,149.68,148.98,107.39$, 107.22, 99.93, 99.01, 98.31, 82.66, 73.96, 72.39, 69.21, 61.70, 51.59, 47.58, 47.42, 46.05, 35.51, 35.37, 23.02, 22.75, 18.76, 18.37, 16.01, 15.91. HR-EI-MS $m / z$ 475.2563; calculated for $\mathrm{C}_{26} \mathrm{H}_{37} \mathrm{O}_{7} \mathrm{~N}_{1}$ : 475.2565 .

Compound 20. The title compound was obtained from xyloketal $\mathrm{B}$ and aniline with a procedure similar to that for compound 16. Yield 93\%; white solid; m. p. 68-69 ${ }^{\circ} \mathrm{C} .{ }^{1} \mathrm{H} \mathrm{NMR}\left(400 \mathrm{MHz}, \mathrm{CDCl}_{3}\right)$ $\delta 7.25(\mathrm{t}, J=8.8 \mathrm{~Hz}, 2 \mathrm{H}), 7.10(\mathrm{~d}, J=8.8 \mathrm{~Hz}, 2 \mathrm{H}), 6.88(\mathrm{t}, J=8.0 \mathrm{~Hz}, 1 \mathrm{H}), 5.35-5.25(\mathrm{~m}, 2 \mathrm{H}), 4.46$ (s, 2H), $4.14(\mathrm{dd}, J=17.2,8.0 \mathrm{~Hz}, 2 \mathrm{H}), 3.49(\mathrm{dd}, J=17.2,8.0 \mathrm{~Hz}, 2 \mathrm{H}), 2.79(\mathrm{t}, J=17.2 \mathrm{~Hz}, 2 \mathrm{H}), 2.65-2.58$ 
(m, 2H), 2.11-2.05 (m, 2H), 1.88-1.83 (m, 2H), $1.48(\mathrm{~s}, 3 \mathrm{H}), 1.46(\mathrm{~s}, 3 \mathrm{H}), 1.04(\mathrm{~d}, J=6.4 \mathrm{~Hz}, 3 \mathrm{H}), 1.01$ $(\mathrm{d}, J=6.4 \mathrm{~Hz}, 3 \mathrm{H}) ;{ }^{13} \mathrm{C} \mathrm{NMR}\left(\mathrm{CDCl}_{3}, 101 \mathrm{MHz}\right) \delta 151.05,149.86,148.38,148.38,129.03,120.59$, 117.51, 107.46, 107.29, 101.23, 99.05, 96.66, 78.84, 73.99, 47.59, 47.46, 46.34, 35.41, 23.04, 22.75, 18.81, 18.73, 18.50, 16.06, 15.97. HR-EI-MS $m / z$ 463.2352; calculated for $\mathrm{C}_{28} \mathrm{H}_{33} \mathrm{O}_{5} \mathrm{~N}_{1}$ : 463.2353.

Compound 21. The title compound was obtained from xyloketal $\mathrm{B}$ and $p$-methoxyaniline with a procedure similar to that for compound 16. Yield 89\%; white solid; m. p. 89-90 ${ }^{\circ} \mathrm{C}$. ${ }^{1} \mathrm{H} \mathrm{NMR}(400 \mathrm{MHz}$, $\left.\mathrm{CDCl}_{3}\right) \delta 7.01(\mathrm{~d}, J=9.2 \mathrm{~Hz}, 2 \mathrm{H}), 6.78(\mathrm{~d}, J=9.2 \mathrm{~Hz}, 2 \mathrm{H}), 5.25-5.17(\mathrm{~m}, 2 \mathrm{H}), 4.38(\mathrm{~s}, 2 \mathrm{H}), 4.13(\mathrm{dd}$, $J=17.2,8.0 \mathrm{~Hz}, 2 \mathrm{H}), 3.73(\mathrm{~s}, 3 \mathrm{H}), 3.49(\mathrm{dd}, J=17.2,8.0 \mathrm{~Hz}, 2 \mathrm{H}), 2.78(\mathrm{t}, J=17.2 \mathrm{~Hz}, 2 \mathrm{H}), 2.64-2.56$ (m, 2H), 2.10-2.06 (m, 2H), 1.87-1.81 (m, 2H), $1.51(\mathrm{~s}, 3 \mathrm{H}), 1.46(\mathrm{~s}, 3 \mathrm{H}), 1.03(\mathrm{~d}, J=6.8 \mathrm{~Hz}, 3 \mathrm{H}), 1.00$ $(\mathrm{d}, J=6.8 \mathrm{~Hz}, 3 \mathrm{H}) ;{ }^{13} \mathrm{C} \mathrm{NMR}\left(\mathrm{CDCl}_{3}, 101 \mathrm{MHz}\right) \delta 154.33,150.96,149.83,148.38,142.55,119.87$, 114.35, 107.43, 107.28, 101.14, 98.99, 98.62, 80.10, 73.99, 55.53, 47.57, 47.49, 47.036, 35.432, 23.06, $22.79,18.74,18.47,16.08,15.98$. HR-EI-MS $m / z$ 493.2458; calculated for $\mathrm{C}_{29} \mathrm{H}_{35} \mathrm{O}_{6} \mathrm{~N}_{1}$ : 493.2459 .

Compound 22. The title compound was obtained from xyloketal B and 4-aminophenol with a procedure similar to that for compound 16. Yield $85 \%$; white solid; m. p. $102-103{ }^{\circ} \mathrm{C} .{ }^{1} \mathrm{H}$ NMR $\left(400 \mathrm{MHz} \mathrm{CDCl}_{3}\right) \delta 6.99(\mathrm{~d}, J=8.8 \mathrm{~Hz}, 2 \mathrm{H}), 6.74(\mathrm{~d}, J=8.8 \mathrm{~Hz}, 2 \mathrm{H}), 5.25-5.16(\mathrm{~m}, 2 \mathrm{H}), 4.37(\mathrm{~s}, 2 \mathrm{H})$, $4.14(\mathrm{dd}, J=17.2,8.0 \mathrm{~Hz}, 2 \mathrm{H}), 3.51(\mathrm{dd}, J=17.2,8.0 \mathrm{~Hz}, 2 \mathrm{H}), 2.79(\mathrm{t}, J=17.2 \mathrm{~Hz}, 2 \mathrm{H})$, $2.66-2.58(\mathrm{~m}, 2 \mathrm{H}), 2.12-2.04(\mathrm{~m}, 2 \mathrm{H}), 1.90-1.84(\mathrm{~m}, 2 \mathrm{H}), 1.47(\mathrm{~s}, 6 \mathrm{H}), 1.04(\mathrm{~d}, J=6.4 \mathrm{~Hz}, 3 \mathrm{H}), 1.01$ $(\mathrm{d}, J=6.4 \mathrm{~Hz}, 3 \mathrm{H}) ;{ }^{13} \mathrm{C} \mathrm{NMR}\left(\mathrm{CDCl}_{3}, 101 \mathrm{MHz}\right) \delta 150.91,150.78,149.73,148.24,142.18,120.16$, 115.77, 109.64, 107.53, 107.36, 101.20, 99.00, 98.76, 80.23, 73.98, 47.53, 47.47, 47.07, 35.39, 23.08, 22.84, 18.69, 18.42, 16.29, 15.98. HR-EI-MS $m / z$ 479.2308; calculated for $\mathrm{C}_{28} \mathrm{H}_{33} \mathrm{O}_{6} \mathrm{~N}_{1}: 479.2309$.

Compound 23. The title compound was obtained from xyloketal $\mathrm{B}$ and $p$-aminobenzoic with a procedure similar to that for compound 16. Yield $88 \%$; white solid; m. p. $128-129^{\circ} \mathrm{C}$. ${ }^{1} \mathrm{H} \mathrm{NMR}\left(400 \mathrm{MHz}, \mathrm{CDCl}_{3}\right)$ $\delta 12.58(\mathrm{~s}, 1 \mathrm{H}), 8.01(\mathrm{~d}, J=8.8 \mathrm{~Hz}, 2 \mathrm{H}), 7.08(\mathrm{~d}, J=8.8 \mathrm{~Hz}, 2 \mathrm{H}), 5.42-5.32(\mathrm{~m}, 2 \mathrm{H}), 4.54(\mathrm{~s}, 2 \mathrm{H}), 4.16$ (dd, $J=17.2,8.0 \mathrm{~Hz}, 2 \mathrm{H}), 3.55-3.49(\mathrm{~m}, 2 \mathrm{H}), 2.81(\mathrm{t}, J=17.2 \mathrm{~Hz}, 2 \mathrm{H}), 2.68-2.60(\mathrm{~m}, 2 \mathrm{H}), 2.11-2.06$ (m, 2H), 1.90-1.86 (m, 2H), $1.51(\mathrm{~s}, 3 \mathrm{H}), 1.48(\mathrm{~s}, 3 \mathrm{H}), 1.05(\mathrm{~d}, J=6.8 \mathrm{~Hz}, 3 \mathrm{H}), 1.03(\mathrm{~d}, J=6.8 \mathrm{~Hz}, 3 \mathrm{H})$; ${ }^{13} \mathrm{C} \mathrm{NMR}\left(\mathrm{CDCl}_{3}, 101 \mathrm{MHz}\right) \delta 171.51,152.21,150.86,149.97,148.25,131.82,120.05,114.94,107.54$, 107.40, 100.82, 99.38, 98.68, 73.97, 47.39, 47.21, 45.53, 35.29, 22.96, 22.71, 18.71, 18.39, 16.01, 15.95. HR-EI-MS m/z 507.2253; calculated for $\mathrm{C}_{29} \mathrm{H}_{33} \mathrm{O}_{7} \mathrm{~N}_{1}$ : 507.2252.

Compound 24. The title compound was obtained from xyloketal $\mathrm{B}$ and paranitroaniline with a procedure similar to that for compound 16. Yield 82\%; white solid; m. p. $70-71{ }^{\circ} \mathrm{C}$. ${ }^{1} \mathrm{H}$ NMR $(400 \mathrm{MHz}$, $\left.\mathrm{CDCl}_{3}\right) \delta 8.14(\mathrm{~d}, J=9.2 \mathrm{~Hz}, 2 \mathrm{H}), 7.06(\mathrm{~d}, J=9.2 \mathrm{~Hz}, 2 \mathrm{H}), 5.42-5.33(\mathrm{~m}, 2 \mathrm{H}), 4.56(\mathrm{~s}, 2 \mathrm{H}), 4.17(\mathrm{dd}$, $J=17.2,8.0 \mathrm{~Hz}, 2 \mathrm{H}), 3.55-3.50(\mathrm{~m}, 2 \mathrm{H}), 2.82(\mathrm{t}, J=17.2 \mathrm{~Hz}, 2 \mathrm{H}), 2.68-2.60(\mathrm{~m}, 2 \mathrm{H}), 2.13-2.04(\mathrm{~m}$, 2H), $1.92-1.88(\mathrm{~m}, 2 \mathrm{H}), 1.51(\mathrm{~s}, 3 \mathrm{H}), 1.49(\mathrm{~s}, 3 \mathrm{H}), 1.06(\mathrm{~d}, J=6.8 \mathrm{~Hz}, 3 \mathrm{H}), 1.04(\mathrm{~d}, J=6.8 \mathrm{~Hz}, 3 \mathrm{H})$; ${ }^{13} \mathrm{C} \mathrm{NMR}\left(\mathrm{CDCl}_{3}, 101 \mathrm{MHz}\right) \delta 153.00,150.90,150.47,150.31,148.56,139.93,125.74,114.46,107.81$, 107.64, 100.47, 99.98, 99.85, 98.99, 76.57, 73.97, 47.57, 47.37, 45.49, 35.46, 35.34, 23.02, 22.78, 18.63, 18.34, 15.99, 15.86. HR-EI-MS $m / z$ 508.2205; calculated for $\mathrm{C}_{28} \mathrm{H}_{32} \mathrm{O}_{7} \mathrm{~N}_{2}: 508.2204$.

Compound 25. The title compound was obtained from xyloketal $\mathrm{B}$ and $p$-fluoro aniline with a procedure similar to that for compound 16. Yield 87\%; white solid; m. p. 79-80 ${ }^{\circ} \mathrm{C}$. ${ }^{1} \mathrm{H}$ NMR $(400 \mathrm{MHz}$, $\left.\mathrm{CDCl}_{3}\right) \delta 7.07(\mathrm{~d}, J=9.2 \mathrm{~Hz}, 2 \mathrm{H}), 6.95(\mathrm{~d}, J=9.2 \mathrm{~Hz}, 1 \mathrm{H}), 6.93(\mathrm{~d}, J=9.2 \mathrm{~Hz}, 1 \mathrm{H}), 5.24(\mathrm{~s}, 2 \mathrm{H}), 4.42$ (s, 2H), $4.15(\mathrm{dd}, J=17.2,8.0 \mathrm{~Hz}, 2 \mathrm{H}), 3.49(\mathrm{dd}, J=17.2,8.0 \mathrm{~Hz}, 2 \mathrm{H}), 2.79(\mathrm{t}, J=17.2 \mathrm{~Hz}, 2 \mathrm{H})$, 
2.67-2.58 (m, 2H), 2.14-2.03 (m, 2H), 1.90-1.84 (m, 2H), $1.48(\mathrm{~s}, 6 \mathrm{H}), 1.05(\mathrm{~d}, J=6.8 \mathrm{~Hz}, 3 \mathrm{H}), 1.02$ $(\mathrm{d}, J=6.8 \mathrm{~Hz}, 3 \mathrm{H}) ;{ }^{13} \mathrm{C} \mathrm{NMR}\left(101 \mathrm{MHz}, \mathrm{CDCl}_{3}\right) \delta 159.24,156.05,150.85,149.89,148.28,144.96$, $144.817,119.78,119.55,115.62,115.34,107.46,107.28,100.84,99.14,98.64,79.52,73.94,70.38$, $47.55,46.99,35.50,35.39,23.04,22.77,18.76,18.41,16.02$. HR-EI-MS $m / z$ 481.2259; calculated for $\mathrm{C}_{28} \mathrm{H}_{32} \mathrm{O}_{5} \mathrm{~N}_{1} \mathrm{~F}_{1}: 481.2259$.

Compound 26. The title compound was obtained from xyloketal B and parachloroaniline with a procedure similar to that for compound 16. Yield 78\%; white solid; m. p. 82-83 ${ }^{\circ} \mathrm{C}$. ${ }^{1} \mathrm{H}$ NMR $(400 \mathrm{MHz}$, $\left.\mathrm{CDCl}_{3}\right) \delta 7.20(\mathrm{~d}, J=8.4 \mathrm{~Hz}, 2 \mathrm{H}), 7.03(\mathrm{~d}, J=8.4 \mathrm{~Hz}, 2 \mathrm{H}), 5.31-5.22(\mathrm{~m}, 2 \mathrm{H}), 4.43(\mathrm{~s}, 2 \mathrm{H}), 4.15(\mathrm{dd}$, $J=17.2,8.4 \mathrm{~Hz}, 2 \mathrm{H}), 3.52(\mathrm{dd}, J=17.2,8.0 \mathrm{~Hz}, 2 \mathrm{H}), 2.79(\mathrm{t}, J=17.2 \mathrm{~Hz}, 2 \mathrm{H}), 2.66-2.58(\mathrm{~m}, 2 \mathrm{H})$, 2.13-2.03 (m, 2H), 1.90-1.85 (m, 2H), $1.48(\mathrm{~s}, 6 \mathrm{H}), 1.47(\mathrm{~s}, 3 \mathrm{H}), 1.05(\mathrm{~d}, J=6.8 \mathrm{~Hz}, 3 \mathrm{H}), 1.02(\mathrm{~d}$, $J=6.8 \mathrm{~Hz}, 3 \mathrm{H}) ;{ }^{13} \mathrm{C} \mathrm{NMR}\left(101 \mathrm{MHz}, \mathrm{CDCl}_{3}\right) \delta 150.84,149.96,149.81,148.34,147.08,128.90,125.55$, $118.85,107.52,107.32,100 . .82,99.24,98.67,78.73,73.98,47.56,47.40,46.54,35.40,23.05,22.78$, 18.70, 18.43, 16.04. HR-EI-MS $m / z$ 497.1965; calculated for $\mathrm{C}_{28} \mathrm{H}_{32} \mathrm{O}_{5} \mathrm{~N}_{1} \mathrm{Cl}_{1}$ : 497.1964 .

Compound 27. The title compound was obtained from xyloketal B and parabromoaniline with a procedure similar to that for compound 16. Yield $88 \%$; white solid; m. p. $83-84{ }^{\circ} \mathrm{C} .{ }^{1} \mathrm{H} \mathrm{NMR}(400 \mathrm{MHz}$, $\left.\mathrm{CDCl}_{3}\right) \delta 7.34(\mathrm{~d}, J=9.2 \mathrm{~Hz}, 2 \mathrm{H}), 6.98(\mathrm{~d}, J=9.2 \mathrm{~Hz}, 2 \mathrm{H}), 5.31-5.22(\mathrm{~m}, 2 \mathrm{H}), 4.43(\mathrm{~s}, 2 \mathrm{H}), 4.15(\mathrm{dd}$, $J=17.2,8.0 \mathrm{~Hz}, 2 \mathrm{H}), 3.51(\mathrm{dd}, J=17.2,8.0 \mathrm{~Hz}, 2 \mathrm{H}), 2.79(\mathrm{t}, J=17.2 \mathrm{~Hz}, 2 \mathrm{H}), 2.64-2.56(\mathrm{~m}, 2 \mathrm{H})$, 2.10-2.01 (m, 2H), 1.88-1.83 (m, 2H), 1.48 (s, 6H), 1.05 (d, J=6.8 Hz, 3H), 1.02 (d, J=6.8 Hz, 3H); ${ }^{13} \mathrm{C} \mathrm{NMR}\left(101 \mathrm{MHz}, \mathrm{CDCl}_{3}\right) \delta 150.82,149.96,149.80,148.33,147.51,131.81,119.21,112.89,107.51$, 107.31, 100.79, 99.24, 98.66, 78.56, 73.97, 47.55, 47.40, 46.44, 35.50, 35.39, 23.04, 22.79, 18.70, 18.46, 16.04, 15.93. HR-EI-MS $m / z$ 541.1455; calculated for $\mathrm{C}_{28} \mathrm{H}_{32} \mathrm{O}_{5} \mathrm{~N}_{1} \mathrm{Br}_{1}: 541.1458$.

Compound 28. The title compound was obtained from xyloketal $\mathrm{B}$ and paraiodoaniline with a procedure similar to that for compound 16. Yield $86 \%$; white solid; m. p. 85-86 ${ }^{\circ} \mathrm{C}$. ${ }^{1} \mathrm{H}$ NMR $(400 \mathrm{MHz}$, $\left.\mathrm{CDCl}_{3}\right) \delta 7.50(\mathrm{~d}, J=8.8 \mathrm{~Hz}, 2 \mathrm{H}), 6.85(\mathrm{~d}, J=8.8 \mathrm{~Hz}, 2 \mathrm{H}), 5.29-5.20(\mathrm{~m}, 2 \mathrm{H}), 4.41(\mathrm{~s}, 2 \mathrm{H}), 4.13(\mathrm{dd}$, $J=17.2,8.4 \mathrm{~Hz}, 2 \mathrm{H}), 3.50(\mathrm{dd}, J=17.2,8.4 \mathrm{~Hz}, 2 \mathrm{H}), 2.77(\mathrm{t}, J=17.2 \mathrm{~Hz}, 2 \mathrm{H}), 2.63-2.59(\mathrm{~m}, 2 \mathrm{H})$, 2.9-2.01 (m, 2H), 1.87-1.82 (m, 2H), $1.46(\mathrm{~s}, 6 \mathrm{H}), 1.03(\mathrm{~d}, J=6.8 \mathrm{~Hz}, 3 \mathrm{H}), 1.01(\mathrm{~d}, J=6.8 \mathrm{~Hz}, 3 \mathrm{H})$; ${ }^{13} \mathrm{C} \mathrm{NMR}\left(101 \mathrm{MHz}, \mathrm{CDCl}_{3}\right) \delta 150.82,149.97,149.82,148.34,148.14,137.76,119.62,107.57,107.32$, $100.82,99.25,98.67,82.75,78.36,73.99,47.55,47.39,46.32,35.39,23.06,22.77,18.69,18.42,16.05$, 15.94. HR-EI-MS $m / z$ 589.1312; calculated for $\mathrm{C}_{28} \mathrm{H}_{32} \mathrm{O}_{5} \mathrm{~N}_{1} \mathrm{I}_{1}: 589.1320$.

Compound 29. First, $50 \mathrm{mg}(0.14 \mathrm{mmol})$ of xyloketal B [16] and $24 \mathrm{mg}(0.28 \mathrm{mmol})$ of morpholine were dissolved in $10 \mathrm{~mL}$ of DMF and stirred, followed by adding $0.05 \mathrm{~mL}(0.28 \mathrm{mmol})$ of $40 \%$ formaldehyde solution, stirred at room temperature for $1 \mathrm{~h}$. The reaction was quenched with water. The aqueous layer was extracted with ethyl acetate, $3 \times 25 \mathrm{~mL}$. The combined organic extracts were washed with saturated ammonium chloride and brine, dried over anhydrous $\mathrm{MgSO}_{4}$ and concentrated in vacuo. Purification by flash chromatography (petroleum ether: ethyl acetate $=5: 1 \sim 2: 1$ ) gave the title compound. Yield 81\%; white solid; m. p. 80-81 ${ }^{\circ} \mathrm{C} .{ }^{1} \mathrm{H}$ NMR (400 MHz, $\left.\mathrm{CDCl}_{3}\right) \delta 4.12-4.03(\mathrm{~m}, 2 \mathrm{H}), 3.77-3.67$ (m, 4H), $3.71(\mathrm{~s}, 2 \mathrm{H}), 3.44$ (q, $J=8.8 \mathrm{~Hz}, 2 \mathrm{H}), 2.77$ (t, $J=17.2 \mathrm{~Hz}, 2 \mathrm{H}), 2.66-2.62(\mathrm{~m}, 2 \mathrm{H}), 2.61-2.52$ (m, 4H), 2.11-1.98 (m, 2H), 1.89-1.79 (m, 2H), 1.47 (s, 3H), $1.43(\mathrm{~s}, 3 \mathrm{H}), 1.03(\mathrm{~d}, J=8.4 \mathrm{~Hz}, 3 \mathrm{H}), 0.99$ $(\mathrm{d}, J=8.4 \mathrm{~Hz}, 3 \mathrm{H}) ;{ }^{13} \mathrm{C} \mathrm{NMR}\left(\mathrm{CDCl}_{3}, 101 \mathrm{MHz}\right) \delta 155.18,150.84,150.03,108.00,107.77,100.04$, 
98.83, 98.59, 74.26, 67.16, 54.62, 53.11, 48.19, 47.97, 36.16, 35.82, 23.52, 23.16, 19.35, 19.03, 16.54, 16.44. HR-EI-MS $m / z$ 445.2458; calculated for $\mathrm{C}_{25} \mathrm{H}_{35} \mathrm{O}_{6} \mathrm{~N}_{1}$ : 445.2459.

Compound 30. The title compound was obtained from xyloketal B and diethylamine with a procedure similar to that for compound 29. Yield 81\%; white solid; m. p. $94-95{ }^{\circ} \mathrm{C}$. ${ }^{1} \mathrm{H} \mathrm{NMR}(400 \mathrm{MHz}$, $\left.\mathrm{CDCl}_{3}\right) \delta 4.15(\mathrm{dd}, J=17.2,8.4 \mathrm{~Hz}, 2 \mathrm{H}), 3.78(\mathrm{q}, J=11.2 \mathrm{~Hz}, 2 \mathrm{H}), 3.49(\mathrm{dd}, J=17.2,8.4 \mathrm{~Hz}, 2 \mathrm{H})$, 2.86-2.80 (m, 2H), 2.70-2.64 (m, 2H), 2.64-2.58 (m, 4H), 2.12-2.03 (m, 2H), 1.92-1.83 (m, 2H), 1.50 $(\mathrm{s}, 6 \mathrm{H}), 1.09(\mathrm{t}, 6 \mathrm{H}), 1.06(\mathrm{~d}, J=6.8 \mathrm{~Hz}, 3 \mathrm{H}), 1.03(\mathrm{~d}, J=6.8 \mathrm{~Hz}, 3 \mathrm{H}) ;{ }^{13} \mathrm{C} \mathrm{NMR}\left(\mathrm{CDCl}_{3}, 101 \mathrm{MHz}\right) \delta$ 155.76, 150.29, 149.37, 107.45, 107.32, 100.76, 98.42, 97.50, 73.93, 49.36, 47.62, 46.31, 35.71, 35.46, 23.13, 22.83, 18.70, 16.07, 11.21. HR-EI-MS $m / z$ 431.2668; calculated for $\mathrm{C}_{25} \mathrm{H}_{37} \mathrm{O}_{5} \mathrm{~N}_{1}: 431.2666$.

\subsection{Biological Evaluation}

\subsubsection{Pharmacological Assays}

Xyloketals derivatives were obtained using the above synthetic method; DMEM (High Glucose) and FBS were purchased from Gibco BRL (Grand Island, NY, USA); JC-1 probe was purchased from Beyotime Institute of Biotechnology (Haimen, China); $\mathrm{H}_{2} \mathrm{O}_{2}$ was purchased from Guangzhou Chemical Reagent Factory (GCRF, Guangzhou, China) and was freshly prepared for each experiment from a 30\% stock solution. All other reagents were purchased from Sigma (St. Louis, MO, USA).

The HUVECs cell line was provided by the Pharmaceutical Biotechnology Centre of Jinan University (Guangdong, China). The cells were cultured in a DMEM medium (High Glucose) (Gibco, Grand Island, NY, USA) supplemented with 10\% fetal bovine serum (FBS) (Gibco, Grand Island, NY, USA), penicillin $(100 \mathrm{U} / \mathrm{mL})$ and streptomycin $(100 \mathrm{U} / \mathrm{mL})$ at $37{ }^{\circ} \mathrm{C}$ in a $5 \% \mathrm{CO}_{2}$ humidified incubator. Endothelial cells appear as "cobblestone" mosaic after reaching confluence under a microscope.

HUVECs were harvested during the logarithmic growth phase and seeded in 96-well plates at a density of $6 \times 10^{4} / \mathrm{mL}$ and cultured at $37{ }^{\circ} \mathrm{C}$ in a $5 \% \mathrm{CO}_{2}$ humidified incubator for $24 \mathrm{~h}$. The cell viability was assessed using the mitochondrial tetrazolium assay (MTT) in HUVECs. The cells were pre-incubated with xyloketals at different concentrations $(10 \mu \mathrm{M}, 1 \mu \mathrm{M})$ for $30 \mathrm{~min}$, followed by exposure to $\mathrm{H}_{2} \mathrm{O}_{2}$ at a concentration of $600 \mu \mathrm{M}$ and additional incubation for $20 \mathrm{~h}$. MTT solution (15 $\mu \mathrm{L} /$ well, $5 \mu \mathrm{g} / \mathrm{mL}$ ) was added and processed to examine the cell viability. The optical density was read at $\lambda=570 \mathrm{~nm}$ using a Thermo Multiskan FC plate reader. At the tested concentration, all of the xyloketals showed no significant effects on cell viability.

\subsubsection{Construction and Validation of the QSAR Model}

The three-dimensional structures of the compounds were constructed using the SYBYL programming package (version 7.3.5, Tripos, St. Louis, MO, USA). The MMFF94 force field and MMFF94 partial atomic charges were applied to these compounds. In addition, the compounds were minimized using a non-bond cut-off of 8 angstroms and the Powell conjugate-gradient algorithm. The convergence criterion was set to $0.05 \mathrm{kcal} / \mathrm{mol}$. The activities of the compounds at $10 \mu \mathrm{M}$ were expressed using the LOGIT transformation shown in the following formula to give a value in proportion to energy: 


$$
\text { LOGIT }=-\log (\text { tested concentration })+\log \frac{\% \text { cell viability }}{100-\% \text { cell viability }}
$$

The training set and test set were randomly divided out of a total of 35 molecules. A training set of 30 molecules was used to construct the QSAR model. In addition, a training set of 5 molecules was used to validate it. All of the molecules were aligned using the most active compound, 22, as the template. Each compound was mapped onto a 3D lattice with grid points $2.0 \AA$ apart. The mapped region was created automatically by the program with an attenuation factor of 0.3 . The electrostatic, hydrophobic, donor and acceptor columns were used to construct the model. The model was constructed using the partial-least-squares (PLS) analysis without any column filtering.

The robustness of the model was addressed based on the internal cross-validation using the leave-one-out (LOO) procedure and the external validation of the test set. All of the statistical parameters are listed in Table 3.

\subsubsection{Mitochondrial Membrane Potentials Assay}

The JC-1 probe was used to measure the mitochondrial depolarization in HUVECs. Briefly, HUVECs were cultured in six-well plates at a density of $2.5 \times 10^{5} / \mathrm{mL}$, incubated with $\mathbf{2 3}$ and $\mathbf{2 4}$ at different concentrations $(25 \mu \mathrm{M}$ and10 $\mu \mathrm{M})$ for $30 \mathrm{~min}$, then exposed to $400 \mu \mathrm{M} \mathrm{H}_{2} \mathrm{O}_{2}$ for $20 \mathrm{~h}$. According to the instructions for the test kits, all cells were collected into $1.5-\mathrm{mL}$ tubes, incubated with JC-1 for $20 \mathrm{~min}$ at $37^{\circ} \mathrm{C}$ and rinsed twice with PBS. The mitochondrial membrane potentials $(\Delta \Psi \mathrm{m})$ were monitored by determining the relative amounts of dual emissions from JC-1 monomers or aggregates using a BD FACS Aria flow cytometry. The red/green fluorescence was calculated using the Flowjo (v7.6.5, Ashland, OR, USA).

\subsubsection{Statistics}

Results are presented as mean \pm S.E.M. Comparisons between multiple groups were performed using the Excel by $t$-test. Differences were considered to be significant at $p \leq 0.05$.

\section{Conclusions}

The water insolubility of the xyloketal compounds from marine fungus may be challenging for further clinical development. Therefore, a new series of derivatives with the introduction of amino groups at the C-12 and C-13 positions of xyloketal B were designed and synthesized to improve the solubility and biological activity. All 28 new derivatives and seven known compounds $(\mathbf{1 4}, \mathbf{1 5}, \mathbf{3 1}-\mathbf{3 5})$ were evaluated for their protection against $\mathrm{H}_{2} \mathrm{O}_{2}$-induced HUVEC injury. The results indicated that some compounds exhibited strong anti-oxidative activities, especially compounds 23 and 24, which displayed the best excellent protective activities out of all of the derivatives. Then, a CoMSIA was constructed using the SYBYL programming package (version 7.3.5) to explain the structural activity relationship of the xyloketal derivatives. A 3D QSAR model generated using the CoMSIA was analyzed and provided good advice to modify the molecules for better activity in the future. Compounds $\mathbf{2 3}$ and $\mathbf{2 4}$, which had the most remarkable anti-oxidative activities, were further examined in the JC-1 mitochondrial membrane potential (MMP) assay of HUVECs. The results showed that compound $\mathbf{2 3}$ and $\mathbf{2 4}$ would significantly 
inhibit $\mathrm{H}_{2} \mathrm{O}_{2}$-induced the decrease in the cell mitochondrial membrane potential $(\Delta \Psi \mathrm{m})$ at $25 \mu \mathrm{M}$. In conclusion, we designed and synthesized a new series of xyloketal derivatives to improve solubility and biological activity. Among them, compounds $\mathbf{2 3}$ and $\mathbf{2 4}$ effectively protected HUVECs against oxidative damage and further mitochondrial membrane integrity impairment. These derivatives will be new candidates for the treatment of CVD.

\section{Acknowledgments}

This work was supported by the National Natural Science Foundation of China (21172271, 81202454), the Natural Science Foundation of Guangdong Province, China (Grant No. S2011020001231) and Major Scientific and Technological Special Project of Administration of Ocean and Fisheries of Guangdong Province (A201301C08). We are indebted to Haibin Luo, School of Pharmaceutical Sciences, Sun Yat-sen University for providing the SYBYL programming package (version 7.3.5).

\section{Author Contributions}

Conceived and designed the experiments: S. Liu, R. Luo, J. Pang; Performed the experiments: S. Liu, R. Luo, Q. Xiang, X. Xu; Analyzed the data: S. Liu, R. Luo, L. Qiu, J. Pang; Wrote the paper: S. Liu, R. Luo, J. Pang.

\section{Abbreviations}

3D-QSAR three-dimensional quantitative structure-activity relationship

As atherosclerosis

BOP (benzotriazol-1-yloxy)tris(dimethylamino)phosphonium hexafluorophosphate

CoMSIA a comparative molecular similarity indices analysis

CVD cardiovascular disease

DCM dichloromethane

DIEA $\quad N, N$-diisopropylethylamine

DMF $\quad N, N$-dimethylformamide

DMSO dimethyl sulfoxide

FACs fluorescence activating cell sorter

FCM flow cytometry

H2DCFDA 2',7'-dihydrodichlorofluorescein diacetate

$\mathrm{H} 2 \mathrm{O} 2 \quad$ hydrogen peroxide

$\mathrm{HCHO}$ formaldehyde

HUVECs human umbilical vein endothelial cells

LOO leave-one-out

MAPK mitogen-activated protein kinase

MMP mitochondrial membrane potential

$\mathrm{MPP}+\quad$ 1-methyl-4-phenylpyridinium

NMR nuclear magnetic resonance

OGD oxygen-glucose deprivation 
OxLDL oxidized low density lipoprotein

PLS partial-least-squares

ROS reactive oxygen species

SAR structure-activity relationship

THF tetrahydrofuran

\section{Conflicts of Interest}

The authors declare no conflict of interest.

\section{References}

1. Yang, B.H.; Oo, T.N.; Rizzo, V. Lipid rafts mediate $\mathrm{H}_{2} \mathrm{O}_{2}$ prosurvival effects in cultured endothelial cells. FASEB J. 2006, 20, 1501-1503.

2. Liu, L.; Gu, L.; Ma, Q.; Zhu, D.; Huang, X. Resveratrol attenuates hydrogen peroxide-induced apoptosis in human umbilical vein endothelial cells. Eur. Rev. Med. Pharmacol. Sci. 2013, 17, 88-94.

3. Kamata, H; Hirata, H. Redox regulation of cellular signalling. Cell. Signal. 1999, 11, 1-14.

4. Favero, T.G.; Zable, A.C.; Abramson, J.J. Hydrogen peroxide stimulates the $\mathrm{Ca}^{2+}$ release channel from skeletal muscle sarcoplasmic reticulum. J. Biol. Chem. 1995, 270, 25557-25563.

5. Suhara, T.; Fukuo, K.; Sugimoto, T.; Morimoto, S.; Nakahashi, T.; Hata, S.; Shimizu, M.; Ogihara, T. Hydrogen peroxide induces up-regulation of Fas in human endothelial cells. J. Immunol. 1998, 160, 4042-4047.

6. Sabri, A.; Byron, K.L.; Samarel, A.M.; Bell, J.; Lucchesi, P.A. Hydrogen peroxide activates mitogen-activated protein kinases and $\mathrm{Na}^{+}-\mathrm{H}^{+}$exchange in neonatal rat cardiac myocytes. Circ. Res. 1998, 82, 1053-1062.

7. Cyrne, L.; Marques, V.O.; Marinho, H.S.; Antunes, F. $\mathrm{H}_{2} \mathrm{O}_{2}$ in the induction of NF-kB-dependent selective gene expression. Methods Enzymol. 2013, 528, 173-188.

8. Xia, Z.Y.; Liu, M.; Wu, Y.; Sharma, V.; Luo, T.; Ouyang, J.P.; McNeill, J.H. N-acetylcysteine attenuates TNF-alpha-induced human vascular endothelial cell apoptosis and restores eNOS expression. Eur. J. Pharmacol. 2006, 550,134-142.

9. Martinou, J.C.; Green, D.R. Breaking the mitochondrial barrier. Nat. Rev. Mol. Cell Biol. 2001, 2, 63-67.

10. Guido, K.; Bruno, D.; Michele, R.R. The mitochondrial death/life regulator in apoptosis and necrosis. Annu. Rev. Physiol. 1998, 60, 619-642.

11. Lin, Y.C.; Wu, X.Y.; Feng, S.; Jiang, G.; Luo, J.H.; Zhou, S.N.; Vrijmoed, L.L.P.; Jones, E.B.G.; Krohn, K.; Steingrover, K.; et al. Five unique compounds: Xyloketals from mangrove fungus Xylaria sp. from the South China Sea coast. J. Org. Chem. 2001, 66, 6252-6256.

12. Wu, X.Y.; Liu, X.H.; Lin, Y.C.; Luo, J.H.; She, Z.G.; Li, H.J.; Chan, W.L.; Antus, S.; Kurtan, T.; Elsasser, B.; et al. Xyloketal F: A strong L-calcium channel blocker from the mangrove fungus Xylaria sp. (\#2508) from the South China Sea coast. Eur. J. Org. Chem. 2005, 12, 4061-4064. 
13. Chen, W.L.; Qian, Y.; Meng, W.F.; Pang, J.Y.; Lin, Y.C.; Guan, Y.Y.; Chen, S.P.; Liu, J.; Pei, Z.; Wang, G.L. A novel marine compound xyloketal B protects against oxidized LDL-induced cell injury in vitro. Biochem. Pharmacol. 2009, 78, 941-950.

14. Zhao, J.; Li, L.; Ling, C.; Li, J.; Pang, J.Y.; Lin, Y.C.; Liu, J.; Huang, R.X.; Wang, G.L.; Pei, Z.; et al. Marine compound Xyloketal B protects PC12 cells against OGD-induced cell damage. Brain Res. 2009, 1302, 240-247.

15. Lu, X.L.; Yao, X.L.; Liu, Z.Y.; Zhang, H.; Li, W.; Li, Z.X.; Wang, G.L.; Pang, J.Y.; Lin, Y.C.; $\mathrm{Xu}$, Z.L.; et al. Protective effects of xyloketal B against $\mathrm{MPP}^{+}$-induced neurotoxicity in Caenorhabditiselegans and PC12 cells. Brain Res. 2010, 1332, 110-119.

16. Xu, Z.; Li, Y.; Xiang, Q.; Pei, Z.; Liu, X.; Lu, B.; Chen, L.; Wang, G.; Pang, J.; Lin, Y. Design and synthesis of novel xyloketal derivatives and their vasorelaxing activities in rat thoracic aorta and angiogenic activities in zebrafish angiogenesis screen. J. Med. Chem. 2010, 53, 4642-4653.

17. Li, Z.X.; Chen, J.W.; Feng, Y.; Huang, Y.Y.; Zhao, L.Y.; Li, J.; Su, H.X.; Liu, J.; Pang, J.Y.; Lin, Y.C.; et al. Xyloketal B exhibits its antioxidant activity through induction of HO-1 in vascular endothelial cells and zebrafish. Mar. Drugs 2013, 11, 504-522.

18. Li, S.C.; Shen, C.Z;; Guo, W.Y.; Zhang, X.F.; Liu, S.X.; Liang, F.Y.; Xu, Z.L.; Pei, Z.; Song, H.C.; Qiu, L.Q.; et al. Synthesis and neuroprotective action of xyloketal derivatives in Parkinson's Disease models. Mar. Drugs 2013, 11, 5159-5189.

19. Sheng, C.Q.; Zhang, W.N.; Ji, H.T.; Zhang, M.; Song, Y.L.; Xu, H.; Zhu, J.; Miao, Z.Y.; Jiang, Q.F.; Yao, J.Z.; et al. Structure-based optimization of azole antifungal agents by CoMFA, CoMSIA, and molecular docking. J. Med. Chem. 2006, 49, 2512-2525.

20. Zhao, H.P.; Moroni, E.; Yan, B.; Colombo, G.; Blagg, B.S.J. 3D-QSAR-assisted design, synthesis, and evaluation of novobiocin analogues. Med. Chem. Lett. 2013, 4, 57-62.

21. Fleury, C.; Mignotte, B.; Vayssière, J.L. Mitochondrial reactive oxygen species in cell death signaling. Biochimie 2002, 84, 131-141.

22. Chen, Q.; Vazquez, E.J.; Moghaddas, S.; Hoppel, C.L.; Lesnefsky, E.J. Production of reactive oxygen species by mitochondria. J. Biol. Chem. 2003, 278, 36027-36031.

23. Pettigrew, J.D.; Bexrud, J.A.; Freeman, R.P.; Wilson, P.D. Total synthesis of (+/-)-xyloketal D and model studies towards the total synthesis of (-)-xyloketal A. Heterocycles 2004, 62, 445-452.

24. Rodriguez, R.; Adlington, R.M.; Moses, J.E.; Cowley, A.; Baldwin, J.E. A new and efficient method for o-ouinone methide intermediate generation: application to the biomimetic synthesis of ( \pm )-alboatrin. Org. Lett. 2004, 6, 3617-3619.

25. Krohn, K.; Riaz, M. Total synthesis of (+)-xyloketal D, a secondary metabolite from the mangrove fungus Xylaria sp. Tetrahedron Lett. 2004, 45, 293-294.

26. Pettigrew, J.D.; Freeman, R.P.; Wilson, P.D. Total synthesis of (-)-xyloketal D and its enantiomer-Confirmation of absolute stereochemistry. Can. J. Chem. 2004, 82, 1640-1648.

27. Pettigrew, J.D.; Wilson, P.D. Synthesis of xyloketal A, B, C, D and G analogues. J. Org. Chem. 2006, 71, 1620-1625.

28. Pettigrew, J.D.; Wilson, P.D. Total synthesis of (-)-xyloketal A. Org. Lett. 2006, 8, 1427-1429.

29. Krohn, K.; Riaz, M.; Flörke, U. Synthesis of xyloketals, natural products from the mangrove fungus Xylaria sp. Eur. J. Org. Chem. 2004, 1261-1270. 
30. Xu, Z.L.; Li, Y.Y.; Lu, B.T.; Pang, J.Y.; Lin, Y.C. An expedient approach to the benzopyran core: application to synthesis of the natural products $( \pm)$-xyloketals and ( \pm )-alboatrin. Chin. J. Chem. 2010, 28, 2441-2446.

31. Gong, G.H.; Qin, Y.; Huang, W.; Zhou, S.; Yang, X.H.; Li, D. Rutin inhibits hydrogen peroxide-induced apoptosis through regulating reactive oxygen species mediated mitochondrial dysfunction pathway in human umbilical vein endothelial cells. Eur. J. Pharmacol. 2010, 628, 27-35.

32. Bresgen, N.; Karlhuber, G.; Krizbai, I.; Bauer, H.; Bauer, H.C.; Eckl, P.M. Oxidative stress in cultured cerebral endothelial cells induces chromosomal aberrations, micronuclei, and apoptosis. J. Neurosci. Res. 2003, 72, 327-333.

(C) 2015 by the authors; licensee MDPI, Basel, Switzerland. This article is an open access article distributed under the terms and conditions of the Creative Commons Attribution license (http://creativecommons.org/licenses/by/4.0/). 